\title{
FARM MACHINERY USE AND THE AGRICULTURAL MACHINERY INDUSTRIES IN INDIA: STATUS, EVOLUTION, IMPLICATIONS, AND LESSONS LEARNED
}

\author{
Madhusudan Bhattarai, Gajendra Singh, Hiroyuki Takeshima, \\ and Ravindra S. Shekhawat
}

\begin{abstract}
Over the last several decades, India has seen a continuous spread of tractor use as well as growth in its domestic tractor manufacturing industry, despite relatively slow wage growth and a slow decline in the employment share of the agricultural sector. By now, arguably as much as 90 percent of the country's farm area may be prepared by tractors. India is now the largest tractor market in the world, purchasing more than 90 percent of the 660,000 tractors it produces per year. The annual value of tractors sold in India is more than US $\$ 5$ billion per year. This study reviews the evolution of agricultural mechanization, particularly tractors, in India. In doing so, it provides some rough indicators of the extent of mechanization (particularly the spread of tractor use) at different historical phases, emphasizing that India's experiences up to 1990 are as important as the lessons since then. Substantial infrastructure endowments (in terms of roads, for example), which were already high in the 1960s, and investments into rural electrification, as well as knowledge accumulation through the importation of a large number of tractors early on, are likely to have helped the growth of domestic tractor manufacturing. Diverse custom hiring services for tractors and combine harvesters have emerged to serve areas that are profitable, with relatively little direct support from the government. The private sector has also stepped up to provide facilitating services to connect service providers and farmers. Empirical analyses of the impact of tractor ownership and tractor/combine harvester use confirms many hypotheses about the farm-level impact of mechanization in India. Despite the typically small landholding in India, tractor ownership is led by the motive to expand farm size. Tractors are more bullock saving than labor saving, whereas combine harvesters are more strongly labor saving. Combine harvesters are more yield enhancing than tractors, but land preparation by tractors may indirectly enhance yields through the increased use of chemical fertilizer.
\end{abstract}


All of these patterns provide important lessons for other countries that are still at an early stage of mechanization.

\section{Historical Background and Evolution of Farm Mechanization in India}

This section takes a historical perspective on the development and evolution of farm machinery use in India, supplemented by numerical data and facts from across the states of India as well as information on changes that have taken place over the years.

Table 3.1 summarizes growth in the use of farm machinery and related agricultural factors, as well as selected agricultural performance metrics, over recent decades. Agricultural land in India has expanded by only 5 percent since 1960 , but grain yields have increased by 300 percent, partly due to the growth in land-saving technologies (irrigation and fertilizers). However, the use and density of farm tractors has also increased considerably during this time.

Information is scarce regarding the extent of tractor use, in terms of the share of agricultural area prepared by tractors. However, various sources of information and back-of-the-envelope calculations, detailed in the note accompanying Bhattarai et al. (2018 Table 2.1), can offer likely estimates. The share was likely to have been about 10 percent in 1980 and 20 percent in 1990 . Therefore, by 1990, India was likely to have exceeded many African countries in its extent of tractor adoption for land preparation. Thus, for African countries today, the experiences in India up to 1990 may be particularly important.

Tractors were first introduced in India in 1914 by the British government for reclaiming land and clearing lands of brush and shrubs. The tractor industry in India has grown particularly fast in the last 50 years, especially since the early 1990s, when Indian industrial sectors (including the production, import, and export of tractors and their parts) became liberalized. ${ }^{1}$

The historical development of tractor and other farm machinery use in India can be separated into five different phases (Bhattarai et al. 2018, Table 2.2). In parallel, there were also major shifts in national and regional

1 As described in the section of this article titled "Machinery Purchase, Manufacturing, and Import Policies," before 1992/1993, a government permit and license were necessary to manufacture, import, or export tractors. After 1992/1993, all of these restrictions were lifted. At present, anybody can set up a tractor factory in India without any license or permit. 
TABLE 3.1 Change in use of farm machinery and related factors of Indian agriculture, 1960-2012/2013

\begin{tabular}{|c|c|c|c|c|c|c|c|c|}
\hline Item & Unit & 1960 & 1970 & 1980 & 1990 & 2000 & 2010 & $\begin{array}{l}2012 / \\
2013\end{array}$ \\
\hline $\begin{array}{l}\text { Agricultural land } \\
\text { (net cropped area) }\end{array}$ & million ha & 133 & 140 & 140 & 143 & 143 & 142 & 140 \\
\hline Irrigated area & $\%$ & 18.32 & 23.04 & 28.84 & 34.03 & 41.11 & 44.99 & 47.62 \\
\hline Cropping intensity & $\%$ & 115 & 118 & 123 & 130 & 133 & 136 & 139 \\
\hline Grain yield & $\mathrm{kg} / \mathrm{ha}$ & 700 & 860 & 1,000 & 1,300 & 1,600 & 1,950 & 2,130 \\
\hline $\begin{array}{l}\text { Nutrient use (N, } \mathrm{P} \text {, } \\
\text { and } \mathrm{K} \text { ) }\end{array}$ & $\mathrm{kg} / \mathrm{ha}$ & 2.00 & 13.61 & 31.95 & 67.55 & 90.12 & 142.35 & 131.36 \\
\hline $\begin{array}{l}\text { No. of irrigation } \\
\text { pumps }\end{array}$ & million & 0.4 & 3.3 & 6.2 & 12.9 & 19.5 & 28.0 & 52.8 \\
\hline No. of draft animals & million & 80 & 83 & 73 & 71 & 60 & 50 & 48 \\
\hline Agricultural labor & million & 131.1 & 125.7 & 148.0 & 185.3 & 234.1 & 263.1 & - \\
\hline Total no. of tractors & 1,000 & 37 & 146 & 531 & 1150 & 2633 & 5005 & 5811 \\
\hline $\begin{array}{l}\text { Tractors per } 1,000 \\
\text { ha of net crop area }\end{array}$ & $\begin{array}{l}\text { no./ } \\
1,000 \text { ha }\end{array}$ & 0.3 & 1.0 & 3.8 & 8.1 & 18.6 & 35.4 & 41.5 \\
\hline $\begin{array}{l}\text { Crop area per } \\
\text { tractor }\end{array}$ & ha & 3,594 & 959 & 264 & 124 & 54 & 28 & 24 \\
\hline No. of power tillers & 1,000 & - & 9.6 & 16.2 & 32.3 & 114.7 & 259.2 & 312.7 \\
\hline $\begin{array}{l}\text { Approximate share } \\
\text { of area plowed by } \\
\text { tractors }\end{array}$ & $\%$ & 一 & 3 & 10 & 20 & 40 & 80 & 90 \\
\hline
\end{tabular}

Source: Bhattarai et al. (2018, Table 2.1).

Note: $-=$ data not available $; \mathrm{K}=$ potassium; $\mathrm{N}=$ nitrogen; $\mathrm{P}=$ phosphorus.

policies as well as shifts in macroeconomic policies, which also affected the adoption and use of farm machinery.

At present, even small and medium-size farmers, with 2-3 ha of landholdings, have started to own tractors on an individual basis. These owners hire out their tractors to fellow farmers and others in their villages for both farm and nonfarm uses, making their tractor purchasing decision more of an entrepreneurial move, based on a prospectus of its benefits from rental services, than a simple investment in plowing their own lands. This phenomenon has led to an extraordinary growth in tractor use in India during the last 40 years. Further discussions on the growth pattern of the tractor market, factors associated with the growth of tractor use in India, and the entry of new tractor manufacturers since 1961 can be found in Bhattarai and others (2017) and in Singh (2015). 


\section{Demand for Mechanization in India}

\section{Trends in Machinery Use and Ownership by Farm Size}

Table 3.2 shows the change in average landholding size of five types of farmers from 1983 to 2010/2011, as well as a snapshot of tractor ownership among medium to large farmers in 2009 . Over time, the farm size distribution has shifted toward small and marginal (in terms of both average size and share of farmers), whereas, as shown above, adoption of tractors has continued rising during the same period. This pattern roughly suggests that tractor use for land preparation has spread in India without a significant increase in farm size.

In 2009, tractor ownership was still concentrated among medium to large farms, with 38 percent of large farmers (those with more than $10 \mathrm{ha}$ ) owning tractors, 18 percent of medium-size farmers (with 2-10 ha), and less than 1 percent of smallholding and marginal farmers (those with less than 2 ha of land). The large and medium-size farmers with tractors have been providing hiring services to enable tractor use among smallholders.

Tractor usage varies spatially across India as well. Table 3.3 shows the distribution of tractor availability across the states of India in 1982 versus 2012. In 1982, almost 60 percent of the tractors in India were concentrated in three northern states: Uttar Pradesh (27 percent), Punjab (21 percent), and Haryana (12 percent). This share had shrunk to less than 40 percent by 2012 . However, the concentration is still high in these three states because they accounted for only 18 percent of the cropped area in India in 2010.

In many respects, the development path of farm machinery use in India is unique, with growth in the use of other farm machinery mirroring that of tractors. India is one of the largest markets for four-wheel tractors (4WTs) in the world (both in volume of annual production and in sales). Likewise, the pace of growth in the use of combine harvesters, mechanical threshers, and other farm machinery in the country has also expanded at a massive scale during recent years. Table 3.4 summarizes the annual sales (or market size) of tractors and related farm machinery in India in recent years.

\section{TYPES OF TRACTORS}

Most tractors purchased in India are 4WTs, and the share of two-wheel tractors (2WTs) remained low from 2005 from 2015, while sales of 4WTs more than doubled (Figure 3.1). In general, less than 10 percent of total tractor sales are $2 \mathrm{WTs}$, in contrast to many other countries in Southeast Asia, despite the fact that more than 80 percent of farmers in India are smallholders, with less than 2 ha of landholdings. In fact, the expansion and diffusion of 2 WTs has 
TABLE 3.2 Trends of farm holdings in India, 1983 to 2010/2011

\begin{tabular}{|c|c|c|c|c|c|c|c|c|c|}
\hline \multirow[b]{2}{*}{ Category of holdings } & \multicolumn{4}{|c|}{ No. of holdings (million) } & \multirow{2}{*}{$\begin{array}{c}\text { Tractor } \\
\text { penetration } \\
\text { (2009) }\end{array}$} & \multicolumn{4}{|c|}{ Total area (million ha) } \\
\hline & 1983 & $\begin{array}{l}2000 / \\
2001\end{array}$ & $\begin{array}{l}2005 / \\
2006\end{array}$ & $\begin{array}{l}2010 / \\
2011\end{array}$ & & 1983 & $\begin{array}{l}2000 / \\
2001\end{array}$ & $\begin{array}{l}2005 / \\
2006\end{array}$ & $\begin{array}{l}2010 / \\
2011\end{array}$ \\
\hline Marginal (< 1 ha) & 44.5 & 75.4 & 83.7 & 92.4 & - & 17.5 & 29.8 & 32.0 & 35.4 \\
\hline Small (1-2 ha) & 14.7 & 22.7 & 23.9 & 24.7 & - & 20.9 & 32.1 & 33.1 & 35.1 \\
\hline Semi-medium (2-4 ha) & 11.6 & 14.0 & 14.1 & 13.8 & $18 \%$ & 32.4 & 38.2 & 37.9 & 37.5 \\
\hline Medium (4-10 ha) & 8.2 & 6.6 & 6.4 & 5.9 & & 49.6 & 38.2 & 36.6 & 33.7 \\
\hline Large (> $10 \mathrm{ha})$ & 2.4 & 1.2 & 1.1 & 1 & $38 \%$ & 42.9 & 21.1 & 18.7 & 17.4 \\
\hline All holdings & 81.4 & 119.9 & 129.2 & 137.8 & - & 163.3 & 159.4 & 158.3 & 159.1 \\
\hline Ha/holding & n.a. & n.a. & n.a. & n.a. & - & 2.01 & 1.33 & 1.23 & 1.15 \\
\hline $\begin{array}{l}\text { Share of marginal and } \\
\text { small farmers (\%) }\end{array}$ & 72.6 & 81.8 & 83.3 & 85.0 & - & 23.5 & 38.8 & 41.1 & 44.3 \\
\hline
\end{tabular}

Source: Shah and Kanodia (2015); Goel and Kumar (2013).

Note: $-=$ data not available; n.a. $=$ not applicable.

TABLE 3.3 Distribution of tractors across selected states in India, 1982 and 2012

\begin{tabular}{lccccc}
\hline & \multicolumn{2}{c}{1982} & & \multicolumn{2}{c}{2012} \\
\cline { 2 - 3 } \cline { 5 - 6 } State & Number $(\mathbf{1 , 0 0 0})$ & \% of India & & Number $(1,000)$ & \% of India \\
\hline Uttar Pradesh & 141.4 & 27.16 & & $1,106.1$ & 19.03 \\
Rajasthan & 54.3 & 10.43 & & 699.9 & 12.04 \\
Madhya Pradesh & 24.5 & 4.71 & & 660.6 & 11.37 \\
Punjab & 106.7 & 20.50 & & 517.7 & 8.91 \\
Haryana & 61.5 & 11.81 & & 516.6 & 8.89 \\
Gujarat & 27.8 & 5.34 & & 495.1 & 8.52 \\
Maharashtra & 21.5 & 4.13 & & 419.2 & 7.21 \\
Karnataka & 20.4 & 3.92 & & 363.9 & 6.26 \\
Andhra Pradesh & 20.9 & 4.01 & & 342.4 & 5.89 \\
Bihar & 14.2 & 2.73 & & 266.6 & 4.59 \\
Tamil Nadu & 14.2 & 2.73 & & 186.7 & 3.21 \\
Odisha & 1.2 & 0.23 & & 83.1 & 1.43 \\
West Bengal & 1.6 & 0.31 & & 35.5 & 0.61 \\
Kerala & 1.3 & 0.25 & & 11.6 & 0.20 \\
All India & 520.6 & 100.00 & & $5,811.1$ & 100.00 \\
\hline
\end{tabular}

Source: Data from India Ministry of Road Transport and Highways (personal communication March 2, 2018). 
TABLE 3.4 Major farm machinery used and annual market size of farm machinery in India, 2014/2015

\begin{tabular}{lcccc}
\hline & $\begin{array}{c}\text { Market } \\
\text { Size annually } \\
\text { (units) }\end{array}$ & $\begin{array}{c}\text { Average } \\
\text { per-unit cost in } \\
\text { US dollars }\end{array}$ & $\begin{array}{c}\text { Average } \\
\text { per-unit cost in } \\
\text { Indian rupees }\end{array}$ & $\begin{array}{c}\text { Annual } \\
\text { industry size in } \\
\text { billion rupees }\end{array}$ \\
\hline Tractor & 600,000 & $7,000-12,000$ & 570,000 & 342.00 \\
Power tiller & 56,000 & 2,100 & 126,000 & 7.06 \\
Combine harvester & $4,000-5,000$ & $22,000-35,000$ & $1,710,000$ & 7.70 \\
Thresher & 100,000 & $1,600-2,500$ & 123,000 & 12.30 \\
Rotavator & $60,000-80,000$ & $1,300-2,000$ & 99,000 & 6.93 \\
Rice transplanter & $1,500-1,600$ & $1,500-2,500$ & 150,000 & 0.62 \\
$\quad$ Walking type & - & $2,500-4,200$ & 201,000 & - \\
$\quad$ Riding type & - & $3,300-16,600$ & 597,000 & - \\
Self-propelled reaper & $4,000-5,000$ & $1,300-2,000$ & 99,000 & 0.45 \\
Zero-till seed drill & $25,000-30,000$ & $750-850$ & 48,000 & 1.32 \\
Multicrop planter & $1,000-2,000$ & $850-1,000$ & 55,500 & 0.08 \\
Laser land leveler & $3,000-4,000$ & $5,800-6,500$ & 369,000 & 1.29 \\
Power weeder & 25,000 & 8,500 & 510,000 & 12.75 \\
\hline
\end{tabular}

Source: CSAM (2014); Shah and Kanodia (2015); Singh (2015).

Note: US\$1 = 65 Indian rupees in 2014/2015. — = data not available.

been confined to only a few states, such as Karnataka, Kerala, Odisha, and some states in the northeast.

Although formal analyses of the reasons for the dominance of $4 \mathrm{WTs}$ among tractors in India have been limited, informal interactions with local experts suggest the following potential reasons. First, in India, 2WTs are well accepted by farmers in paddy-growing states (eastern and southern India), but not in dry regions due to the need for engines with higher horsepower for plowing. Second, in India, registration is not available for $2 \mathrm{WTs}$, so they are not permitted on highways and busy roads, limiting their nonfarm or hauling uses during the off-season. Furthermore, despite the expansion of irrigation, 60 percent of farmland in India is still rainfed (FAO 2018) or under farming systems that rotate rice cultivation with rainfed nonrice crops (Pingali 2007).

The typical horsepower of a $4 \mathrm{WT}$ in India is $30-40 \mathrm{hp}$ (Figure 3.2). Although the share of higher-horsepower tractors has gradually increased since the period 2000-2009, more than 80 percent of 4WTs were still of less than $50 \mathrm{hp}$ in 2012. The average horsepower among tractors in India has therefore been lower than that of the 50-70 hp 4WTs boasted by African governments. 
FIGURE 3.1 Two-wheel and four-wheel tractor sales in India between 2005 and 2015

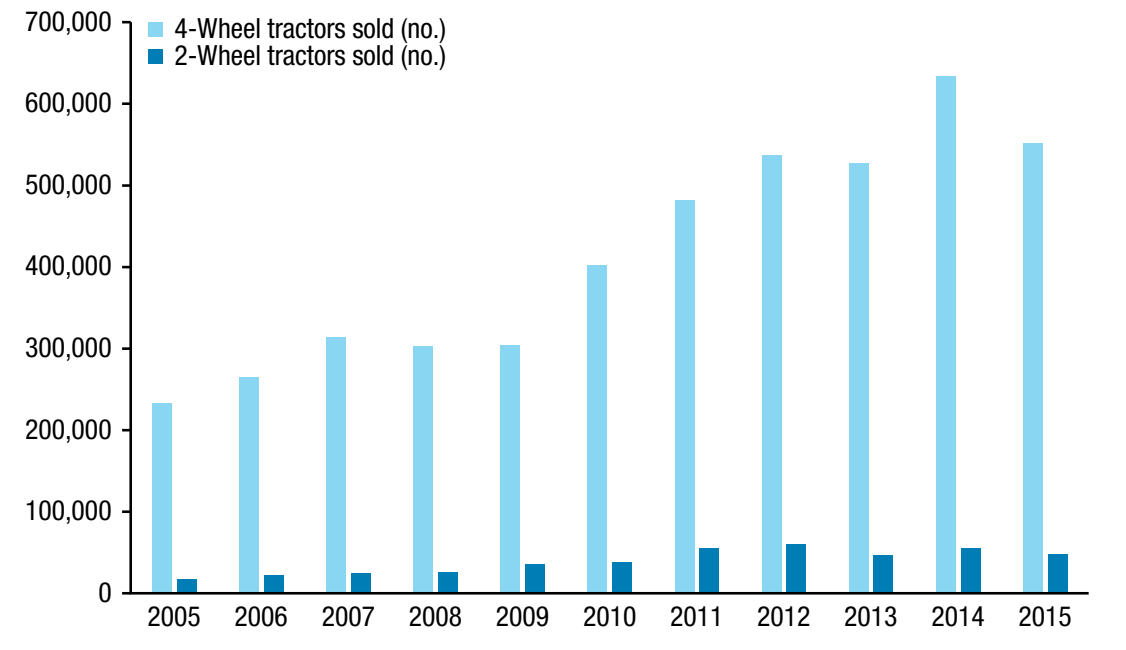

Source: Shah and Kanodia (2015).

FIGURE 3.2 Breakdown by horsepower of tractors sold in India between 2000 and 2012

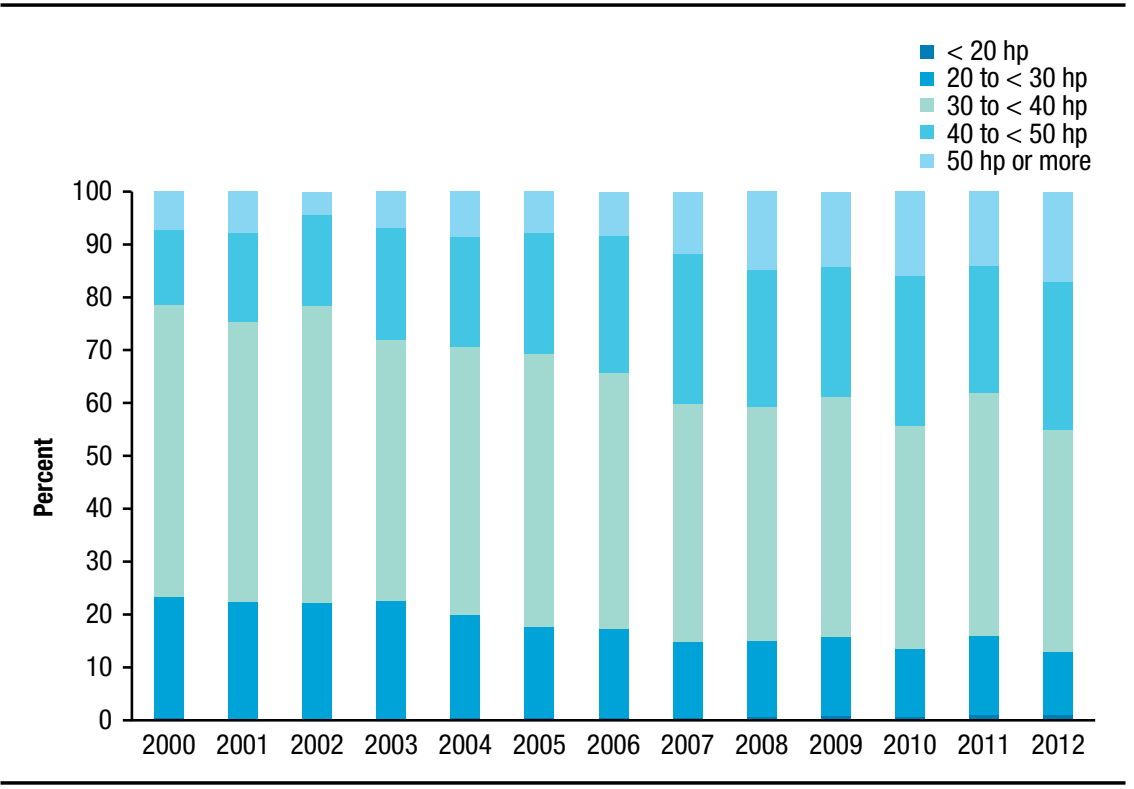

Source: CSAM (2014); Bhattarai et al. (2017). 


\section{Agroecological Conditions, Cropping Systems, and the Spread of Farm Machinery}

The adoption levels of farm mechanization vary greatly by crop type and operation type. Generally, mechanization is more common for paddy and wheat cultivation than for other crops, except planting for paddy (Table 3.5). Land plowing, seedbed preparation, and spraying of pesticides for all major crops in India have been more mechanized than other operations.

Compared with paddy and wheat, harvesting of coarse cereals (such as sorghum and pearl millet), pulses, and vegetables is much less mechanized (Table 3.5). If the rate of mechanization does not speed up for several operations on these crops, farmers may lose any comparative advantage in growing them. In fact, the acreage of many of the pulses and coarse cereals (notably sorghum) has already been declining in India in recent years.

The agricultural production pattern in India can be divided into more than 20 distinct agroecological zones, with distinct cropping patterns and cropping intensities in each zone (Figure 3.3). Currently, tractors, combine harvesters, and other farm machinery are used more intensively in Haryana, Punjab, and the western part of Uttar Pradesh (that is, the western part of the Indo-Gangetic Basin), as well as in central India (the major rice-wheat cultivation belt), than elsewhere. Likewise, soybeans are cultivated widely in central India (the states of Madhya Pradesh and Maharashtra), with their crop area expanding partly due to the ready availability of combine harvesters, which allow timely harvesting and land preparation for the following season.

\section{Labor-Land Ratio and Tractor Density}

In principle, farm mechanization should grow faster in places with less availability of labor per unit of landholding - that is, where the labor force is scarce-due to substitution effects among the factors of production for agricultural commodities. In India, the evidence on this relationship is mixed, as reflected in Figure 3.4. India itself is a region with one of the highest densities of rural population, where tractors (and power tillers in close neighbor Bangladesh) have spread rapidly in the recent past. Agricultural labor density is also very high in most parts of India, as in the South Asia region as a whole. On the other hand, Haryana and Punjab, two of the states with the highest tractor densities, also have some of the lowest agricultural labor densities in India. Still, several states with agricultural labor densities as low as those of Haryana and Punjab (Gujarat, Karnataka, Kerala, and Rajasthan) have lower tractor densities. 
TABLE 3.5 Percentage of mechanization by major crop and by operation in India, 2013

\begin{tabular}{lcccc}
\hline Crop & Seedbed preparation & $\begin{array}{c}\text { Sowing/planting/ } \\
\text { transplanting }\end{array}$ & $\begin{array}{c}\text { Weed and pest } \\
\text { control }\end{array}$ & $\begin{array}{c}\text { Harvesting and } \\
\text { threshing }\end{array}$ \\
\hline Paddy & $85-90$ & $5-10$ & $80-90$ & $70-80$ \\
Wheat & $90-95$ & $80-90$ & $70-80$ & $80-90$ \\
Potatoes & $90-95$ & $80-90$ & $80-90$ & $70-80$ \\
Cotton & $90-95$ & $50-60$ & $50-60$ & 0 \\
Maize & $90-95$ & $80-90$ & $70-80$ & $50-60$ \\
Gram & $90-95$ & $50-60$ & $60-70$ & $30-40$ \\
Sorghum & $80-90$ & $30-50$ & $60-70$ & $20-30$ \\
Millet & $80-90$ & $30-40$ & $60-70$ & $20-30$ \\
Oilseeds & $80-90$ & $30-40$ & $60-80$ & $20-30$ \\
Vegetables & $70-80$ & $5-10$ & $80-90$ & $<1$ \\
Horticultural crops & $60-70$ & $30-40$ & $40-50$ & $<1$ \\
\hline
\end{tabular}

Source: FICCI (2015).

Note: ${ }^{\text {a }}$ The reported harvester use on paddy, wheat, and potatoes seems high, and this may be the case for a few states in the north, but not for the country as a whole.

Table 3.6 shows correlation coefficients between tractor density and selected variables across the states, estimated for 1982 and 2012. The strength of spatial correlation between tractor density and agricultural labor wage declined over this period; it remained the same between tractor density and agricultural labor density. However, the strength of the correlation has increased for the average operational agricultural landholding, with its correlation coefficient with tractor density having slightly increased in 2012 over that of 1982.

Overall, mechanization growth in India has reflected key demand characteristics. First, tractor use in India has grown without significant farm size growth and even with continued land fragmentation. This trend is consistent with the hypothesis that the demand for mechanization was to meet the increasing farm power requirements for land productivity improvement, rather than to improve productivity by expanding scale. Second, the speed of growth in tractor use has been heterogeneous across regions and states within India, although the growth curves have gradually converged, with lagging regions starting to catch up. Third, $4 \mathrm{WTs}$ are still common, possibly due to the rice-nonrice crop rotation that is still common in India, as well as certain soil characteristics. 


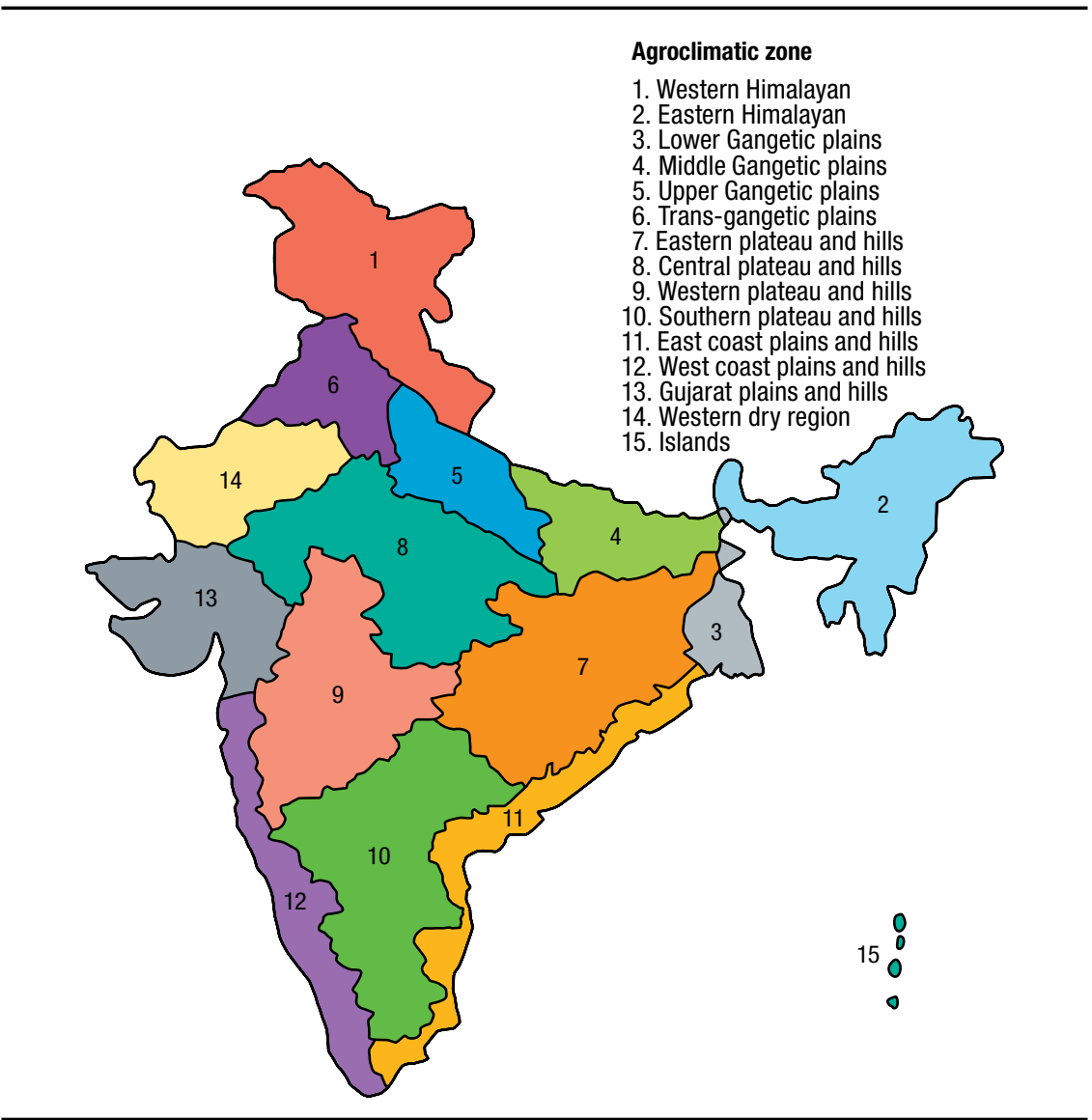

Source: India, MOEIT (2018).

\section{Supply-Side Factors}

This section describes supply-side factors for growth and expansion in the use of farm machinery such as tractors, harvesters, and other major farm implements, including (1) development and dissemination of farm machinery technologies; (2) support and incentives for effectively engaging the private sector in the adoption and diffusion of farm machinery technology; and (3) the private sector's role in developing machinery technology, markets, and custom hiring services. In the federal structure of India, issues related to agricultural and farm machinery support fall under state jurisdiction. As a result, each state of India is pursuing its own farm machinery support policies and related 
FIGURE 3.4 Tractor density and agricultural labor density across the states of India, 2012

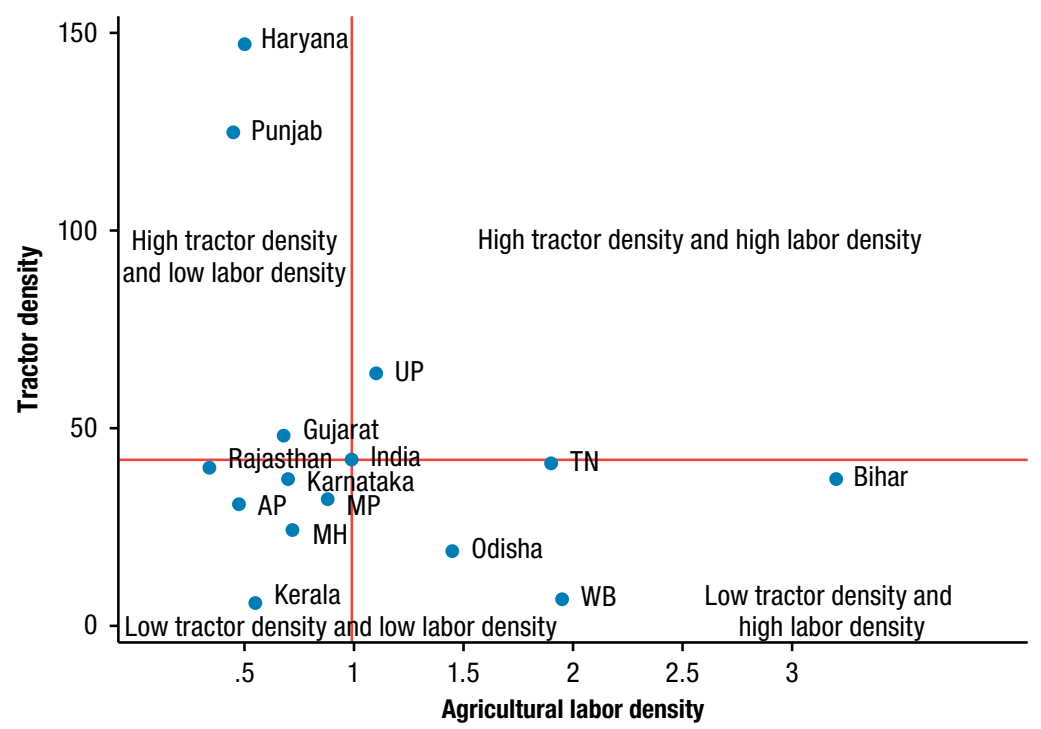

Source: Bhattarai et al. (2017).

Note: For the vertical axis, density is in units per 1,000 hectares; for the horizontal axis, density is in units per hectare. AP = Andhra Pradesh; MH = Maharashtra; MP = Madhya Pradesh; TN = Tamil Nadu; UP = Uttar Pradesh; WB = West Bengal.

TABLE 3.6 Correlation coefficients between tractor density and selected factors in India, 1982 and 2012

\begin{tabular}{lcc}
\hline & \multicolumn{2}{c}{ Correlation coefficient $(\mathbf{r})$} \\
\cline { 2 - 3 } Factor associated with changes in tractor density & 1982 & 2012 \\
\hline Real wage rate (Indian rupees/day) & $0.60^{\star \star}$ & 0.02 \\
Agricultural labor density (no. of ag. laborers/ha) & -0.38 & -0.37 \\
Average operational holding (ha) & 0.438 & $0.639^{\star \star}$ \\
Intensity of irrigation (\%) & $0.714^{\star \star \star}$ & $0.468^{\star}$ \\
Cropping intensity (\%) & $0.794^{\star \star \star}$ & $0.594^{\star \star}$ \\
Scheduled commercial bank credit (Indian rupees/ha) & 0.382 & 0.053 \\
\hline
\end{tabular}

Source: Adapted from Bhattarai et al. (2017, Table 4.3).

Note: Asterisks indicate the statistical significance: ${ }^{\star \star \star} 1 \%,{ }^{\star \star} 5 \%,{ }^{\star} 10 \%$. 
other inducements (subsidy programs) to promote farm machinery in its jurisdiction in line with location-specific constraints.

\section{Machinery Purchase, Manufacturing, and Import Policies}

In India, importing a diverse set of foreign tractors constituted an important part of technology transfer policies, which helped the country raise its knowledge levels, later inducing the growth of domestic manufacturing. This process was partly led by the premise that an inappropriate foreign technology can be a powerful stimulus to indigenous technology generation (Morehouse 1980). Throughout the 1950s, the Indian government's policy was to permit the import of "conventional" technologies, including tractors, on the condition that these technologies did not exist in the country (Morehouse 1980, 2143). Tractor imports grew throughout the 1960 s, from 3,000 tractors per year in 1961 to 16,000 per year in 1970, with a total of about 50,000 tractors imported in 10 years (Patel and Gandhi 1996; Singh, Verma, and Tandon 1984). In 1970, tractors were imported from various countries, including the USSR (3,621), Czechoslovakia (3,247), Poland $(3,131)$, the UK $(2,845)$, and Romania (1,743), among others (Patel and Gandhi 1996). Imports were largely led by the private sector, although there were also often concessional agreements. ${ }^{2}$ For example, Escorts Ltd., which started as an importer and domestic agent for Massey Ferguson, built up a dealer network in North India and, after Massey Ferguson moved to South India, formed a joint venture with Ford Motor Company USA (Morehouse 1980). By 1979, after the Indian government's shift toward technological self-reliance in the 1970s, the Escorts $35 \mathrm{hp}$ tractor (manufactured through a mixture of the original Polish technologies and substantial indigenous modification) became a leader, with 21 percent of the market share (Morehouse 1980). The important message here is that the growth of domestic tractor manufacturing in India was preceded by the importation of a large number of tractors, which helped the private sector build its knowledge about tractors and their design, setting the stage for the growth of private-sector research and development $(R \& D)$ for further modifications in the 1970s.

The Indian government shifted its focus toward technological self-reliance in the 1970s and set up more regulatory trade policies. These included import duties (30 percent) and an eventual ban on imports in 1973 (Binswanger 1978), an excise duty (about 18 percent), and central and state sales taxes

2 For example, Aurora and Morehouse (1972) mentioned that some of the imported tractor components from Czechoslovakia were subsidized. 
(about 4 percent and 7 percent, respectively), as well as a 40-120 percent import duty and an ad valorem duty on imported tractor components and raw materials in the mid- to late 1970s, among other miscellaneous taxes (Singh 1978). However, it is important to note that these increased duties and taxes were the government's attempt to raise tax revenues, taking advantage of the growing demand for tractors. In addition, a gift program was introduced, allowing citizens residing abroad to buy a tractor in foreign currency and send it free of taxes to friends or relatives in India (Farrington 1986).

\section{SUBSIDIES ON TRACTORS}

Since the 1960s, subsidies had been provided for pump sets in India (Singh 1978). The history of subsidies on tractors in India before the 1980s is somewhat sketchy, but they are thought to have had generally more limited effects on tractor purchases than in some other countries, such as Pakistan (Binswanger 1978). ${ }^{3}$ By the early 1980s, government subsidies for machinery such as tractors were 25-33 percent (Binswanger and Donovan 1987) of the purchase price. It is important to note that the subsidy rates in India have historically been lower than rates in other countries that provided similar subsidies. The subsidies on tractors and other agricultural machines have remained until now, although maximum subsidy rates by machine, type of buyer, and region have changed. ${ }^{4}$ On top of the fixed subsidy offered under various central government programs, depending upon local conditions, the state-level agency will often grant a further level of subsidy.

\section{FINANCING}

As in other countries, the Indian government has also provided financial support for the purchase of tractors and other agricultural machines. Although evidence is generally scarce regarding the actual impacts of these supports, it is noteworthy that in India, the share of tractors purchased with bank credit has historically been high. For example, in the early 1980s, 90 percent of tractors in India had been purchased using bank credit (Singh, Verma, and Tandon 1984), and this share has remained high.

In the 1970s, to encourage mechanization, the government directed banks to offer loans of up to 85 percent for farmers to purchase tractors and implements, with a repayment period of $7-10$ years and at concessionary

3 For example, Pakistan had been providing 40-50 percent subsidies on tractors since the 1960s (Binswanger 1978).

4 For example, the maximum subsidy rates are 25 percent for tractors, 40 percent for power tillers and all other agricultural machines, 50 percent for machinery purchased by women farmers and scheduled castes and tribes, and 90 percent for purchases in the northeastern states. 
rates of 10-14 percent per year (Suri 1978; Singh 1978; Farrington 1986). Similarly, the government encouraged banks to extend equipment manufacturers credit at 10-15 percent interest rates (Singh 1978). After 1975, the National Bank for Agriculture and Rural Development granted \$175 million ${ }^{5}$ (at the then-current exchange rate, amounting to perhaps $\$ 500$ million to $\$ 600$ million at the 2010 rate) for refinancing tractor loans (Farrington 1986). In the 1980s, the government continued to direct banks to reserve 11 percent of their total credit for tractor purchases by medium-size and large farmers at interest rates of 10-11 percent (Singh, Verma, and Tandon 1984).

The support for financing has continued since then. Recognizing the importance of the agricultural sector in India's development, the government and the Reserve Bank of India have played a vital role in creating a broadbased institutional framework for meeting the increasing credit requirements of the sector. Agricultural policies in India have been reviewed from time to time to maintain pace with the changing requirements of the agricultural sector, one of the priority sectors for lending among scheduled commercial banks. The government has stipulated a target of 18 percent net bank credit for the sector. Microfinance and the Kisan (Farmer) Credit Card Scheme have emerged as the major policy developments to address the distributional aspects of credit in recent years.

Cooperative banks currently have a major share ( 51.5 percent $)$ in providing loans to farmers, followed by commercial banks (36.9 percent). About 95 percent of tractor sales in India are on credit. Various institutions provide credit for tractors and machinery-public-sector banks, private-sector banks, publically funded financial institutions, cooperative banks, and private sector-operated financial institutions (usually subsidiaries of the same tractor companies selling tractors to farmers).

\section{IMPORT POLICIES}

Once India had reached near-self-sufficiency in tractors in the late 1970s, as mentioned above, the focus of trade policies shifted to imports of tractor components and spare parts. ${ }^{6}$ Until the 1980s, the Indian government placed tighter restrictions on imports of tractor components than did other South Asian countries (Farrington 1986). ${ }^{7}$ Imports of specialized sophisticated

5 Dollar figures are US dollars throughout the chapter.

6 Although Indian tractor exports have also grown, the majority of markets for Indian tractors have been domestic. For example, in 2008, exports accounted for only 14 percent of total tractor sales in India (Sarkar 2013).

7 Tractor imports dropped to marginal levels after 1978, as India's domestic manufacturing matured (Singh, Verma, and Tandon 1984). 
agricultural machines and certain spare parts to the collaborative manufacturers and actual consumers were allowed, but with an import duty of 40 percent and a countervailing duty of 10 percent (Singh, Verma, and Tandon 1984). Nonetheless, tractor manufacturing in India kept growing fast in the 1980s, with annual production growing from around 80,000 in 1980 to about 150,000 in 1991, immediately before liberalization (Singh 1998). Thus, it is important to note that even before liberalization in the early 1990s, both the demand for and the supply of tractors had already grown considerably in India, and therefore the growth in India up to the 1980s offers important lessons for African countries today. After 1991, licenses and permits were no longer needed to import or manufacture tractors, other farm machinery, or their parts and engines. In addition, the quota on imports was replaced by a uniform, transparent tax. This liberalization is likely to have helped sustain the momentum of growth that had already occurred in the 1980s (Pray and Nagarajan 2014).

Today, under the government's import policy, India levies full duty on the import of spare parts and components for agricultural implements, made up of a customs duty part and an excise duty part. For finished agricultural implements, the countervailing duty, chargeable on assessable value, is nil; the basic customs duty, chargeable on the same, is 7.5 percent; and the additional duty chargeable is 4 percent. These import duties and tariffs are still set by the Central Excise Tariff Act of 1985, which also sets a 0 percent rate of excise duty for these items. However, recently, certain machinery parts and components are being classified by the Central Excise Department under other headings that attract excise duty of about 12 percent even if they are used for agriculture. ${ }^{8}$

\section{LICENSING, REGULATIONS, AND REGISTRATION}

As mentioned above, since 1991/1992, no licensing has been needed in India for setting up a new tractor manufacturing plant. Moreover, until 2014, by which time the use of machines such as tractors had already spread widely across the country, only four testing centers offered quality testing and certification of new tractors and implements.

8 Specifically, they include power take-off shafts and gear boxes (used in agricultural implements such as rotary tillers, rotary slashers, rotary harrows, post-hole diggers, and balers), hooks (used in agricultural implements such as harrows and agricultural trailers), springs (used in agricultural implements such as cultivators, harrows, and rotary tillers), spindles and hubs (used in agricultural implements such as disc plows, disc ridgers, and disc harrows), and others. 
Farmers have to register their tractors with local road and transportation departments even for agricultural and local transport use in the villages. Nowadays, almost all tractor owners register their tractors so that they can drive them on roads and highways for nonfarm-sector uses. Unlike tractors, some other machines, such as power tillers, are not registered, preventing them from moving on the highways and roads outside of villages. This is a major difference between India and other countries in South Asia, where power tillers are often used for hauling farm and nonfarm goods from villages to urban centers and back.

\section{POLICIES ON FUELS}

Fuel policies in India, in particular those on diesel, have gradually shifted from taxation before the oil shocks of the 1970s and 1980s to subsidization since then. Before the first oil shock, in the early 1970s, high-speed diesel oil was taxed because it was used by road transportation that competed with government-owned railways; gasoline was also taxed because it was assumed to be the fuel of wealthy automobile owners. Central taxes on diesel would usually amount to 300 percent (Desai 1981). In addition, until 1974, a 100 percent import duty was imposed on diesel fuel (Binswanger 1978).

Until the 1980s, the government controlled production and pricing in the energy sectors (Sarkar and Kadekodi 1988). After the second oil shock, in 1980, and the consequent price spikes in diesel, the Indian government shifted its emphasis to meeting the energy requirements of the agricultural sector (Moulik 1988). Diesel subsidies expanded gradually throughout the 1980s, and diesel prices were also kept low by relaxing a major portion of the excise duty (Singh, Verma, and Tandon 1984). However, the pace of subsidy expansion was uneven across states. For example, whereas diesel for running a pump was already subsidized as early as 1981 in some states (Srinivasan 1981), in some states in South India, diesel fuel, unlike electricity, was not subsidized even by the late 1980s (Babu and Hallam 1989). By the 1990s, at the national level, India was providing about $\$ 1.3$ billion (in 1990s dollars) in subsidies for diesel (Larsen 1994). Fuel subsidies continued until 2015, after which they were gradually removed.

India has also invested substantially in rural electrification. In spite of limited empirical evidence about the effects of rural electrification on the prices of substitutes such as diesel, it is likely that electrification helped diesel prices

the country, the government now plans to open more than 30 such machinery quality testing centers in the country within a few years. 
remain relatively stable and lower than without electrification. Electrification started in the early 1950s, and by $1975 / 1976$, one-third of the approximately 600,000 villages in India had been electrified (Mukherjee 1978); this share increased to 57 percent by 1980 and to almost 90 percent by 1994 (Fan, Hazell, and Thorat 2000). In the 1980s, the rate for electricity used for agriculture was also kept at approximately 50 percent of that charged for industrial and domestic use (Singh, Verma, and Tandon 1984).

Partly due to these factors, the price of diesel at the pump in India has been lower than in other developing countries, at $\$ 0.23$ per liter in 1991 as opposed to about $\$ 0.55$ per liter among low-income countries, and $\$ 0.91$ as opposed to about $\$ 1.10$ to about $\$ 1.20$ in 2014 (World Bank 2017).

\section{RESEARCH AND DEVELOPMENT}

In India, as in other countries, the private sector has led a significant portion of the $\mathrm{R} \& \mathrm{D}$ related to agricultural mechanization. In the late 1970 s, most major manufacturers in India had some R\&D unit or units associated with the parent mechanical engineering company when a separate joint venture was created to make tractors with foreign collaboration (Morehouse 1980). This trend continued toward the 1980s. By the mid-1980s, capital investments in $\mathrm{R} \& \mathrm{D}$ facilities and recurring $\mathrm{R} \& \mathrm{D}$ expenditures by Indian manufacturers had reached $\$ 5$ million and $\$ 2$ million, respectively (Mohan 1986), equivalent to perhaps $\$ 10$ million and $\$ 4$ million at today's prices. The agricultural machinery industries almost doubled their R\&D spending between the mid-1980s and the mid-1990s (Pray and Nagarajan 2014). By 2008/2009, the industry was spending about $\$ 40$ million (in 2005 prices), of which about half was spent by Indian firms and the remainder by multinational companies (Pray and Nagarajan 2014). Throughout the 1990s and the following decade, the agricultural machinery industry devoted about 1.0 percent of the value of its sales to agricultural spending-low from a global standpoint (with a global average of about 2.7 percent) but still substantial (Pray and Nagarajan 2014). Although the private sector has contributed greatly to this $R \& D$, the public sector has also played a complementary role by developing designs for new equipment, educating engineers, and offering extension programs (Singh, Verma, and Tandon 1984).

\section{POLICIES TOWARD INCLUSIVE GROWTH OF AGRICULTURAL MECHANIZATION}

As noted in the previous sections, the growth of mechanization, including the use of tractors, has been uneven in India, in terms of regional variations of tractor growth, with the level of mechanization growth lagging especially in the eastern and northeastern regions. Therefore, in 2014, the Indian 
government initiated a program called the Sub-Mission on Agricultural Mechanization (SMAM) in its 12th five-year plan (for 2012-2017) (India, MOAFW 2015). The sub-mission will primarily help with modernizing mechanization in areas that are lagging or using old technologies, through financial subsidies on acquiring machinery or establishing machinery rental service centers, among other activities. The proposed funding outlay for this mission during the period of the 12th plan is 35 billion Indian rupees (Rs), or about $\$ 550$ million. ${ }^{10}$ It is important to note that addressing inequality in access to mechanization has been challenging even in countries such as India, and the recent approach of the Indian government may suggest that addressing inequality may be more feasible once overall mechanization (in terms of tractor use) has reached a sufficient level that lagging areas and regions can be more easily identified.

\section{Agricultural Machinery Manufacturing Policies}

India has seen remarkable growth in its domestic manufacturing sector for agricultural machines, including tractors. It is difficult to point out specific policies that led to this growth because there were no specific policies that promoted it. However, the Indian government did contribute to the creation of an enabling environment. Binswanger and Donovan (1987) listed three areas in which the public sector contributes to the development of the machinery manufacturing industry: (1) providing communication and transportation infrastructure, (2) directly assisting the industry through training and $\mathrm{R} \& \mathrm{D}$, and (3) establishing the regulatory framework within which the industry operates. The Indian government has generally performed many of these functions.

In terms of infrastructure, both rural electrification (mentioned earlier) and expansion of the road network have been substantial. Although estimates vary, road density in India has generally been higher than in other countries, with estimates of about $388 \mathrm{~km}$ of roads per $1,000 \mathrm{~km}^{2}$ of area at the beginning of the Green Revolution in the 1960s (Bationo et al. 2011), doubling between 1970 and 1990 (Fan, Hazell, and Thorat 2000). These densities are substantially higher than, for example, those of African countries today, which range from $4 \mathrm{~km}$ in Ethiopia to $11 \mathrm{~km}$ in Kenya to $46 \mathrm{~km}$ in Ghana (World Bank 2017).

Regarding training and $\mathrm{R} \& \mathrm{D}$, as mentioned above, imports of a large number of tractors in the 1960s helped the domestic private sector to study

10 At the 2011/2012 exchange rate of US $\$ 1=$ Rs 45 . 
the machines and develop ideas for modifications and adaptions, as well as manufacturing. Furthermore, India had already had a long history of manufacturing tractor parts; its engine manufacturing industry began in the 1930s, and by 1950, 6 companies were manufacturing 20,000 engines per year (Bell, Dawe, and Douthwaite 1998). These numbers had increased to 32 companies producing 141,000 engines by 1975 . With such an accumulation of local expertise, combined with a long history of manufacturing parts such as engines, the protectionism of the 1970s (regulations on and banning of tractor imports) helped the domestic manufacturing sector grow by facilitating smooth replacement of imported with domestic tractors in the market, without the substantial negative effects of reduced technology transfer speed that also sometimes result from protectionism (Ito 1986). Unlike in many small developing countries elsewhere, the Indian manufacturing sector also benefited from the country's large domestic market, in which annual demand for tractors had already reached 10,000 by the early 1970 s.

Several international tractor manufacturers (such as Ford and Escorts) entered into Indian tractor markets in the 1970s and 1980s. By 1992, there were more than 15 tractor manufacturers producing tractors in India. Since liberalization in the early 1990 s, several mergers among the manufacturers have taken place. Also since then, a few new international (global brand) tractor manufacturing and trading companies have started to produce tractors, combine harvesters, laser land levelers, and other implements in India. The actual market size of each tractor manufacturer varies from year to year (Table 3.7).

Tractor manufacturers in India are usually not allowed to produce attachments and the like; rather, another entity is encouraged to produce these farm implements. As a result, there is a vibrant farm implement and attachment industry in India, with more than 10,000 small-scale farm implement manufacturers scattered all over the country (Table 3.8).

\section{Ownership and Market Institutions for Mechanization Service Provision}

In the early 1970s, public sector-operated custom hiring service centers (CHSCs) were established in many places in India by state-level agricultural inputs corporations to promote farm machinery use along with application of fertilizer and other inputs. But in most states, these public rental service centers could not cover their operating costs. As a result, within a few years of their opening, many were closed down when state governments tightened their budgets. By 1980, most of them had ceased to operate. 
TABLE 3.7 Leading tractor manufacturers in India, 2009/2010 to 2015/2016

\begin{tabular}{lccccccc}
\hline & \multicolumn{7}{c}{ Percentage share in annual production } \\
\cline { 2 - 8 } Manufacturer & $\mathbf{2 0 0 9 /}$ & $\mathbf{2 0 1 0 /}$ & $\mathbf{2 0 1 1 /}$ & $\mathbf{2 0 1 2 /}$ & $\mathbf{2 0 1 3 /}$ & $\mathbf{2 0 1 4 /}$ & \multicolumn{2}{c}{ 2015/ } \\
\hline Mahindra \& Mahindra & $\mathbf{2 0 1 0}$ & $\mathbf{2 0 1 1}$ & $\mathbf{2 0 1 2}$ & $\mathbf{2 0 1 3}$ & $\mathbf{2 0 1 4}$ & $\mathbf{2 0 1 5}$ & \multicolumn{1}{c}{ 2016 } \\
TAFE & 39.55 & 39.84 & 38.60 & 38.47 & 40.08 & 37.72 & 37.71 \\
Escorts & 22.59 & 20.80 & 23.51 & 24.73 & 24.88 & 23.96 & 22.99 \\
Sonalika & 13.12 & 12.04 & 9.78 & 10.27 & 10.13 & 9.55 & 9.00 \\
John Deere & 8.21 & 8.58 & 9.79 & 10.35 & 0.83 & 12.36 & 11.94 \\
New Holland & 8.74 & 9.77 & 9.50 & 7.15 & 9.63 & 7.40 & 8.92 \\
SAME Deutz-Fahr & 4.92 & 6.00 & 5.63 & 6.04 & 7.42 & 5.80 & 5.56 \\
VST Tillers Tractors Ltd. & 0.79 & 1.05 & 1.08 & 0.89 & 5.24 & 1.36 & 1.55 \\
HMT Tractors & 0.87 & 0.84 & 1.13 & 1.37 & 1.10 & 1.01 & 1.37 \\
Force Motors & 1.07 & 0.88 & 0.69 & 0.44 & 0.22 & 0.18 & 0.13 \\
\hline
\end{tabular}

Source: Adapted from Singh, Singh, and Singh (2015).

TABLE 3.8 Status of farm mechanization industry in India, 2014

\begin{tabular}{lc}
\hline Equipment manufacturer & $\begin{array}{c}\text { Number of production } \\
\text { units in India }\end{array}$ \\
\hline Agricultural tractors & 22 \\
Power tillers & 5 \\
Irrigation pumps & 600 \\
Plant protection equipment & 300 \\
Combine harvesters & 48 \\
Reapers & 60 \\
Threshers & 6,000 \\
Seed drills and planters & 2,500 \\
Diesel oil engines & 200 \\
Plows, cultivators, harrows & 5,000 \\
Chaff cutters & 50 \\
Rural artisans & $>1$ million \\
\hline
\end{tabular}

Source: CSAM (2014). 
Over the years, a variety of forms of custom hiring service providers have emerged in the leading states and regions of India, each with a different operational modality. The pace of the growth of custom hiring services for farm machinery has been fast, especially from 2000 onward. The development of vibrant markets for these services in India is one of the reasons for the massive growth of farm machinery use in the last two to three decades. Even marginal and smallholding farmers in India have been effectively using tractors, combine harvesters, and other farm machinery, including the costly laser land leveler, through the development of rental services. The rental market has made the use of these huge and costly machines possible by aggregating services across farmers. Types of ownership and rental services for farm machinery in India can be categorized into the following major groups:

- Individual farmers as owners. Machinery has become more widespread than ever and is available in every village of India. As individual farmers purchase different pieces of equipment, a farmer-to-farmer system of service provision may develop at the local level. Then, as entrepreneurship develops, the farmer-owners may start working together as local service providers (LSPs), renting out several types of machinery. ${ }^{11}$ Eventually, some farmers take on rental services for farm machinery as a major business activity.

- Cooperative and joint ownership among farmers. Cooperative ownership of farm machinery has been most successfully adopted in Punjab, where, since 2010/2011, more than 1,250 farmers' cooperatives have been effectively providing rental services through CHSCs. Though other states (Karnataka and others) have recently attempted such initiatives, none have been as successful as Punjab's.

- Machinery owned and rented out by rural entrepreneurs (LSPs). Several public projects and private businesses are supporting individual rural entrepreneurs to operate as LSPs for rental services. For example, the Cereal Systems Initiative for South Asia supported such LSPs in Bihar, Haryana, Odisha, and eastern Uttar Pradesh.

11 Custom hiring services for grain combines are unique because the equipment goes where the work is, starting in the north for a season, going to the south for a season, and then returning to the north again. Custom hiring rates differ from place to place. An elaborate description of custom hiring services for harvesters, their movements across India, and the economics of their use in wheat cultivation is offered by Bhattarai et al. (2015). 
- Big business (corporation)-owned machinery for bigfarms. Rental programs of this type are initiated in intensively cultivated agricultural pockets of southern India. Examples include (1) rentals from Coromandel Agrico Group, (2) Yanmar Coromandel Agrisolutions Service Centre in Tamil $\mathrm{Nadu}$, and (3) rental services from sprayer manufacturer UPL Ltd. in North India.

- Big private firm-owned farm machinery for organized custom hiring services. In addition to large corporations, individual private firms have also recently started to operate CHSCs with a range of farm machinery at one place, offering services to farmers through various business models. For example, Zamindara Farm Solutions operates a rental program for farm machinery in the state of Punjab.

- Government-promoted CHSCs under a public-private partnership model. Recently some state governments (Andhra Pradesh, Karnataka, and Madhya Pradesh) have provided encouragement and funding support to private industry or nongovernmental organizations (NGOs) through a public-private partnership mode of operation. CHSCs are set up with 50-75 percent of the cost of farm implements supported by the government, with their ownership, operation, and management carried out by a private business or NGO. In this model, a large portion of the investment cost is subsidized by the government. Many other state governments are attempting to replicate Karnataka's recent successful CHSC program.

- Direct government-implemented rental services, such as the Yantradoot program in Madhya Pradesh. Under the Yantradoot Villages Scheme in Madhya Pradesh (in central India), district-level officers of the Department of Agriculture Engineering periodically demonstrate the use of farm implements to farmers in selected villages spread throughout the state and make these implements available for hire to the agricultural community at nominal prices. The designated villages are rotated each year so that all farmers can get the benefit of observing demonstrations of new farm machine technologies within their villages.

There is also an increasing trend toward using smartphone and Web-based technologies to coordinate the demand from the large number of farmers in rural areas with the rental services available to them. CHSCs represent a new business model of rental services for agricultural machinery in India, making machinery and technology accessible to hundreds of smallholding farmers at affordable prices. 
Importantly, these service providers have largely emerged informally, with little direct promotion by the government, because support programs have only recently been initiated (including the aforementioned SMAM, launched in 2014).

Custom hiring service providers have also been emerging for nonconventional machines. Combine harvester service providers have been emerging in Punjab (Singh, Kingra, and Sangeet 2013), where the number of self-propelled and tractor-driven combines has increased from 3,000 and 5,000, respectively, in 2000/2001 to 8,000 and 6,000, respectively, in 2010/2011 (CSAM 2014). Custom hiring services with tractor-pulled zero-till machines have also been emerging, albeit with 60 percent subsidies on machines that typically cost Rs 55,000 (about \$1,000) (Keil, D’Souza, and McDonald 2016). Out of approximately 13 million ha of rice-wheat systems in the Indo-Gangetic Plains, as much as 5 million ha was under zero-till technologies in 2008 (Chauhan et al. 2012). Finally, the number of service providers and contractors for laser land leveling increased from only about 8 in 2005 to an estimated 2,000-4,000 in India by 2010 (IRRI 2010; CSAM 2014) and has kept growing since then. In Punjab, the area under laser land leveling increased from about 1,000 ha in 2005 to 600,000 ha in 2010 (CSAM 2014).

\section{Farm-Level Impacts of Agricultural Mechanization}

This section presents some empirical evidence on the effects of farm machinery use on various outcomes of interest (agricultural performance, crop yield, land size, and so on) in India, using farm household-level panel data from the Village Dynamics in South Asia (VDSA) project of the International Crops Research Institute for the Semi-Arid Tropics (ICRISAT) (ICRISAT 2017). For short, we call this the "ICRISAT-VDSA dataset" or simply "VDSA data." The panel form of household data provides us the opportunity to isolate and quantify more meaningfully the net effects of farm machinery use on key agricultural performance metrics (the outcomes of interest).

The ICRISAT-VDSA dataset has been collected through the support of various donors over the years since the 1970s. The data used in this study were collected from 2001 through 2014. Details of the survey are described in Rao and others (2011a, 2011b) for the 2001-2008 period and on the VDSA project website ${ }^{12}$ for the 2009-2014 period as well as all previous periods. The scope of the ICRISAT-VDSA dataset was to collect detailed information 
on households' agricultural production activities; economic activities including farming, livestock, and nonfarm activities; household resource use; receipts from welfare programs; and coping mechanisms, among other data. The VDSA data contain details on agronomic production practices gathered through a longitudinal survey of farm households across various locations in the semi-arid regions of India. The data are therefore suitable for estimating the impact of mechanization (particularly tractor and combine harvester use) on different indicators of agricultural performance, including crop yield, labor use in farming, and production practices, as well as farm size dynamics.

The sampling frame of the data consists of a total of six villages in Andhra Pradesh and Maharashtra states, which were covered in the first-generation VDSA study conducted between 1975 and 1985. Based on the census of households in these six villages, households were classified into four groups according to farm size and landownership, from which a predetermined number of households were randomly selected for interviews. A total of 446 farm households were selected for interviews in 2001. All of these households, including any that spun off from the original households, were interviewed again annually from 2002 to 2008 . The same households were interviewed again after 2009, when the VDSA project added coverage in eastern India and Bangladesh. Our analyses use only the samples from Andhra Pradesh and Maharashtra states throughout the period 2001-2014, to maintain consistency.

From these samples, we constructed an unbalanced panel, because some households were not always interviewed every year. We analyzed more than 880 farm households as part of these unbalanced panel data. After missing observations were removed, our final sample was 5,692 households for most specifications, although for some models, such as land dynamics analysis, sample sizes were reduced because certain lagged observations had to be used as independent variables.

The results are summarized by topic under the different subheadings below. Technical discussions of empirical methods are provided in this chapter's appendix.

\section{Effects on Farm Size and Farm Size Dynamics}

Table 3.9 summarizes results on farm size dynamics and the effects of tractor ownership. The dependent variable is the growth rate in area cultivated between the current year and the previous year. The significantly positive coefficients of the number of tractors owned, or the binary indicator of owning a tractor at time $t-1$, indicates that these factors significantly increase the 
TABLE 3.9 Tractor investment and farm size dynamics in semi-arid villages in India, 2001-2014

\begin{tabular}{|c|c|c|c|c|c|}
\hline $\begin{array}{l}\text { Dependent variable }= \\
\ln (\text { cultivated })(t)-\ln (\text { cultivated })(t-1)\end{array}$ & Model 1 & Model 2 & Model 3 & Model 4 & Model 5 \\
\hline \multicolumn{6}{|l|}{ Endogenous variable } \\
\hline $\ln ($ cultivated $)(t-1)$ & $\begin{array}{l}-.707^{\star \star \star} \\
(.035)\end{array}$ & $\begin{array}{l}-.573^{\star \star \star} \\
(.053)\end{array}$ & $\begin{array}{l}-.707^{\star \star \star} \\
(.035)\end{array}$ & $\begin{array}{l}-.571^{\star \star \star} \\
(.054)\end{array}$ & $\begin{array}{l}-.802^{\star \star \star} \\
(.074)\end{array}$ \\
\hline In(cultivated)2 $(t-1)$ & n.a. & n.a. & n.a. & n.a. & $\begin{array}{l}.051^{\star \star} \\
(.019)\end{array}$ \\
\hline $\ln ($ land owned $)(t-1)$ & $\begin{array}{l}.417^{\star \star \star} \\
(.061)\end{array}$ & $\begin{array}{l}.390^{\star \star \star} \\
(.056)\end{array}$ & $\begin{array}{l}.419^{\star \star \star} \\
(.060)\end{array}$ & $\begin{array}{l}.392^{\star \star *} \\
(.056)\end{array}$ & $\begin{array}{l}.476^{* \star \star} \\
(.043)\end{array}$ \\
\hline Number of tractors owned $(t-1)$ & $\begin{array}{l}.313^{\star \star *} \\
(.098)\end{array}$ & $\begin{array}{l}.213^{\star \star} \\
(.104)\end{array}$ & n.a. & n.a. & $\begin{array}{l}.115 \dagger \\
(.069)\end{array}$ \\
\hline Owns tractor $(y e s=1)(t-1)$ & n.a. & n.a. & $\begin{array}{l}.306^{\star \star \star} \\
(.097)\end{array}$ & $\begin{array}{l}.199^{\star \star} \\
(.093)\end{array}$ & n.a. \\
\hline \multicolumn{6}{|l|}{ Exogenous variable } \\
\hline Other household characteristics & Included & Included & Included & Included & Included \\
\hline Year dummies & Included & Included & Included & Included & Included \\
\hline 0 -value dummies & Included & Included & Included & Included & Included \\
\hline Number of observations & 3,839 & 3,839 & 3,839 & 3,839 & 3,839 \\
\hline Number of panels & 625 & 625 & 625 & 625 & 625 \\
\hline Number of instruments & 246 & 211 & 246 & 211 & 426 \\
\hline \multicolumn{6}{|l|}{$p$-value } \\
\hline $\mathrm{H}_{0}$ : Model jointly insignificant & .000 & .000 & .000 & .000 & .000 \\
\hline $\mathrm{H}_{0}$ : Overidentified (Hansen test) & .142 & .223 & .136 & .229 & .716 \\
\hline $\mathrm{H}_{0}$ : Autocorrelation & .529 & .778 & .534 & .776 & .364 \\
\hline $\begin{array}{l}\text { Closest lag of endogenous variables } \\
\text { used as instrumental variables }\end{array}$ & 1 & 2 & 1 & 2 & 1 \\
\hline
\end{tabular}

Source: Authors' calculations based on ICRISAT (2017).

Note: Asterisks indicate the statistical significance: ${ }^{\star \star \star} 1 \%,{ }^{\star \star} 5 \%,{ }^{\star} 10 \%, \dagger 15 \%$. Other explanatory variables include $\ln$ (household size —working age), In(household size—dependents), In(completed education of household head, years), $\ln ($ experience of household head). n.a. $=$ not applicable.

growth rate of the operational farm size between $t-1$ and $t$. For the sample at hand, owning a tractor at $t-1$ increases the growth rate of the operational farm size by about 10-30 percentage points, which is potentially substantial. The positive effects of tractor ownership on the growth of operational size hold even after controlling for the dynamics in operational sizes through the variable $\ln$ (cultivated) $(t-1)$ and its squared term, as well as the size of land owned at time $t$. 


\section{Effects on Land Productivity and Adoption of Other Modern Technologies}

\section{EFFECTS ON LABOR AND DRAFT ANIMAL USE}

Table 3.10 presents the household-level effects of tractor use on the use of human labor and of bullocks for land preparation, ${ }^{13}$ estimated through the same panel data specifications as those described above. Similarly, Table 3.11 presents the household-level effects of combine harvester use on the use of labor and bullocks for harvesting and threshing. In both tables, figures for the random-effects tobit model correspond to responses at a sufficiently high level of labor or bullock use (not at a marginal level).

Generally, tractor use for land preparation is mostly bullock saving (Table 3.10), although it is also somewhat labor saving. In the sample at hand, 1.00 hour of using a tractor for land preparation leads to about a 0.84 -hour reduction in the use of bullocks. However, this effect is for all households, including those not using bullocks. Among households actually using bullocks for land preparation, 1.00 hour of tractor use for land preparation substitutes for about 1.04 hours of bullock use for land preparation. The effect on labor use for land preparation is relatively small and generally statistically insignificant.

These patterns are generally consistent with early mechanization experiences in the United States and Japan, where much of the farm power for land preparation had been provided by animals (horses and so on) and the use of tractors substituted for more animal power than human labor.

In contrast, the combine harvester is strictly labor saving (Table 3.11). ${ }^{14}$ On average, 1.00 hour of combine harvester use reduces the labor for harvesting and threshing by approximately 28-29 hours. The use of labor for these activities is also highly responsive to wages, unlike the case for land preparation, shown in Table 3.10. This result is consistent with the generalization in Binswanger (1986) that mechanization of harvesting is profitable only when the wages are sufficiently high and rising, whereas mechanization of land preparation can be profitable even at low wages.

The use of tractors substitutes for animal and human power only in specific operations, rather than for their aggregate use over the whole farming

13 Although some rounds of the ICRISAT-VDSA categorize certain activities as "land preparation," the term is not clearly defined for other rounds. We identify all activities such as harrowing, plowing, land clearing, puddling, and any other land-related preparation, aggregating all of them as "land preparation" to calculate the total labor use, bullock use, and tractor use for land preparation.

14 The use of bullocks for harvesting or threshing was minimal in the samples. 
TABLE 3.10 Effects of tractor use for land preparation on the use of human labor and animal (bullock) traction for land preparation (per year, all production seasons combined)

\begin{tabular}{|c|c|c|c|c|}
\hline \multirow{3}{*}{$\begin{array}{l}\text { Dependent variable } \\
\text { Estimation model }\end{array}$} & \multicolumn{4}{|c|}{ (Hours/year) } \\
\hline & \multicolumn{2}{|c|}{$\begin{array}{l}\text { Labor use for land } \\
\text { preparation }\end{array}$} & \multicolumn{2}{|c|}{$\begin{array}{l}\text { Bullock use for land } \\
\text { preparation }\end{array}$} \\
\hline & $\begin{array}{l}\text { Fixed-effects } \\
\text { SURE }\end{array}$ & $\begin{array}{c}\text { System of } \\
\text { panel tobit } \\
\text { regressions }\end{array}$ & $\begin{array}{l}\text { Fixed-effects } \\
\text { SURE }\end{array}$ & $\begin{array}{c}\text { System of } \\
\text { panel tobit } \\
\text { regressions }\end{array}$ \\
\hline Tractor used for land preparation (hours) & .118 & .076 & $-.837^{\star \star \star}$ & $-1.041^{\star \star \star}$ \\
\hline Farmland owned (acres) & $4.435^{\star \star \star}$ & $4.184^{\star \star \star}$ & $4.358^{\star \star \star}$ & $4.850^{\star \star \star}$ \\
\hline In(bullock rental costs) & n.a. & n.a. & -2.098 & -5.404 \\
\hline In(male labor wage for land preparation) & -1.447 & 2.342 & n.a. & n.a. \\
\hline Other household characteristics & Included & Included & Included & Included \\
\hline Year dummies & Included & Included & Included & Included \\
\hline Village dummies & Included & Included & Included & Included \\
\hline Year * village dummies & Included & Included & Included & Included \\
\hline Intercept & Included & Included & Included & Included \\
\hline Household fixed effects & Fixed effects & CRE & Fixed effects & CRE \\
\hline Number of observations & 5,057 & 5,057 & 5,057 & 5,057 \\
\hline Number of panels & 1,054 & 1,054 & 1,054 & 1,054 \\
\hline$\%$ of uncensored observations & n.a. & 81 & n.a. & 65 \\
\hline $\mathrm{H}_{0}$ : Variables are exogenous & Yes & n.a. & Yes & n.a. \\
\hline
\end{tabular}

Source: Authors' calculations based on ICRISAT (2017).

Note: Asterisks indicate the statistical significance: ${ }^{\star \star \star} 1 \%,{ }^{\star \star} 5 \%,{ }^{\star} 10 \%$. CRE $=$ correlated random effects; n.a. $=$ not applicable; SURE = seemingly unrelated regression.

operation. This point becomes clearer if we assess the effects of overall tractor use (including activities other than land preparation) on the overall use of draft animals or human labor for farming. Table 3.12 presents these results: 1.00 hour of tractor use reduces the overall use of bullocks by about 0.33 hours, which is considerably smaller than the effect of tractors on bullock use for land preparation alone. For human labor, the effects are even weaker and generally insignificant. Thus, the effects of tractor use on animal and labor use vary across farming operations and are more pronounced for land preparation than for other operations. ${ }^{15}$

15 Evidence on gendered labor use in India is scarce, except for one study. Carranza (2014) showed that in contemporary India, plow technology is more likely to be adopted for deep, loamy soils than for shallow, clayey soils, and that tractors are associated with less participation of women in agriculture because in India, deep tillage reduces the use of human labor for subsequent activities (transplanting, fertilizing, weeding, and the like), particularly reducing female labor demand. 
TABLE 3.11 Effects of combine harvester use on the use of human labor for harvesting and threshing (per year, all production seasons combined)

\begin{tabular}{lcc}
\hline Dependent variable & \multicolumn{2}{c}{$\begin{array}{c}\text { Labor use for harvesting and threshing } \\
\text { (hours/year) }\end{array}$} \\
\hline Estimation model & $\begin{array}{c}\text { Fixed-effects } \\
\text { SURE }\end{array}$ & $\begin{array}{c}\text { System of panel tobit } \\
\text { regressions }\end{array}$ \\
\hline Combine harvester use (hours) & $-28.556^{\star \star}$ & $-28.138^{\star \star \star}$ \\
Farmland owned (acres) & $59.616^{\star \star \star}$ & $58.742^{\star \star *}$ \\
In(male labor wage) & $-134.941^{\star \star}$ & $-234.671^{\star \star}$ \\
Used irrigation (yes $=1$ ) & $222.852^{\star \star *}$ & n.a. \\
Other household characteristics & Included & Included \\
Year dummies & Included & Included \\
Village dummies & Included & Included \\
Year * village dummies & Included & Included \\
Intercept & Included & Included \\
Household fixed effects & Fixed effects & CRE \\
\hline Number of observations & 5,057 & 5,057 \\
Number of panels & 1,054 & 1,054 \\
$\%$ of uncensored observations & n.a. & 98 \\
$\mathrm{H}_{0}$ : Variables are exogenous & Yes & n.a. \\
\hline
\end{tabular}

Source: Authors' calculations based on ICRISAT (2017).

Note: Asterisks indicate the statistical significance: ${ }^{\star \star \star} 1 \%,{ }^{\star \star} 5 \%,{ }^{\star} 10 \%$. CRE $=$ correlated random effects; n.a. $=$ not applicable; SURE = seemingly unrelated regression.

These findings are consistent with other recent findings that the adoption of tractors does not simply substitute for human labor or animal traction, but changes the overall returns to scale in production, and the use of labor or animals is also affected more profoundly by such transformations of overall production technologies than by piecemeal adoption for a single process (Takeshima 2017).

\section{EFFECTS ON CHEMICAL FERTILIZER USE INTENSITY}

Table 3.13 presents the estimated effects of tractor use for land preparation on chemical fertilizer use intensity. Generally, 1-hour per acre increase in tractor use for land preparation (approximately a 50 percent increase on average) is associated with increased chemical fertilizer use by about $1-2 \mathrm{~kg} / \mathrm{acre}$, or approximately 3 percent. Therefore, although the effects are significantly positive, they are modest. This result is consistent with the conventional view that tractor use leads to yield-enhancing operations only modestly or not at all (for example, Jayasuriya, Te, and Herdt 1986). However, a recent study in the 
TABLE 3.12 Effects of tractor use on overall labor and animal use at the household level

\begin{tabular}{lccc}
\hline & Bullock use/hour & & Labor use/hour \\
\cline { 2 - 3 } Variable & $\begin{array}{c}\text { System of panel tobit } \\
\text { regressions }\end{array}$ & & $\begin{array}{c}\text { Fixed-effects } \\
\text { SURE }\end{array}$ \\
\hline Tractor use (hours) & $-.327^{*}$ & 2.862 \\
Farmland owned (acres) & $11.024^{\star \star \star}$ & $118.629^{\star \star *}$ \\
In(bullock rental costs) & $-26.190^{\star}$ & $-267.111^{*}$ \\
In(male labor wage) & -15.597 & $-329.656^{\star}$ \\
Other household characteristics & Included & Included \\
Year dummies & Included & Included \\
Village dummies & Included & Included \\
Year * village dummies & Included & Included \\
Household fixed effects & Fixed effects & CRE \\
Intercept & Included & & Included \\
\hline Number of observations & 5,057 & 5,057 \\
Number of panels & 1,054 & & 1,054 \\
$\%$ of uncensored observations & 95 & & n.a. \\
$R$-squared & .621 & & .554 \\
\hline
\end{tabular}

Source: Authors' calculations based on ICRISAT (2017).

Note: Asterisks indicate the statistical significance: ${ }^{\star \star \star} 1 \%,{ }^{\star \star} 5 \%,{ }^{\star} 10 \%$. CRE $=$ correlated random effects; n.a. $=$ not applicable; SURE = seemingly unrelated regression.

Terai zone of Nepal, adjacent to Bihar state in India, suggests that mechanization may raise the returns on chemical fertilizer use at the intensive margins (Takeshima et al. 2017). Future studies in India, especially in areas bordering Nepal and sharing common agroecological conditions, should investigate whether similar effects hold in India.

\section{EFFECTS OF TRACTOR AND COMBINE HARVESTER USE ON YIELDS OF KEY CROPS}

We next consider how tractor and combine harvester use affects the yields of key crops. Given the prevalence of various crops in the areas covered by the VDSA, we select rice and cotton in kharif season, wheat in rabi season, and sugarcane (an annual) to investigate. Utilizing detailed information from the VDSA, we estimate effects on yields, controlling for fixed effects of plot, season, and variety.

Table 3.14 summarizes the estimated yield effects. Generally, the use of tractors does not seem to affect yield. Only for cotton does tractor use appear to exhibit weakly significant effects on yield (statistical significance at the 
TABLE 3.13 Effects of tractor use for land preparation on the use of chemical fertilizer per acre (per year, all production seasons combined)

\begin{tabular}{lccc}
\hline & \multicolumn{3}{c}{ Chemical fertilizer use } \\
\cline { 2 - 4 } Dependent variable & $\begin{array}{c}\text { (kg per acre/ } \\
\text { year) }\end{array}$ & $\begin{array}{c}\text { In } \begin{array}{c}\text { (kg per acre/ } \\
\text { year) }\end{array} \\
\text { (kg per acre/ } \\
\text { year) }\end{array}$ \\
\hline Estimation model & $\begin{array}{c}\text { Fixed-effects } \\
\text { SURE }\end{array}$ & $\begin{array}{c}\text { Fixed-effects } \\
\text { SURE }\end{array}$ & $\begin{array}{c}\text { System of panel } \\
\text { tobit regressions }\end{array}$ \\
\hline Tractor use for land preparation (hours per acre) & .678 & $.054^{\star \star \star}$ & $1.725^{\star \star}$ \\
In(male labor wage for land preparation) & -1.187 & -.017 & $19.111^{\star}$ \\
In(fertilizer price) & $-18.086^{\star \star \star}$ & $-.370^{\star \star *}$ & $-10.312^{\star \star}$ \\
Used irrigation (yes =1) & $14.010^{\star \star \star}$ & $.151^{\star \star *}$ & 3.933 \\
Other household characteristics & Included & Included & Included \\
Year dummies & Included & Included & Included \\
Village dummies & Included & Included & Included \\
Year * village dummies & Included & Included & Included \\
Household fixed effects & Fixed effects & Fixed effects & CRE \\
Intercept & Included & Included & Included \\
\hline Number of observations & 5,057 & 5,057 & 5,057 \\
Number of panels & 1,054 & 1,054 & 1,054 \\
$\%$ of uncensored observations & n.a. & n.a. & 80 \\
$p$-value & n.a. & n.a. & n.a. \\
$\mathrm{H}_{0}$ : Model jointly insignificant & .000 & .000 & .000 \\
$\mathrm{H}_{0}$ : Variables are exogenous & Yes & Yes & n.a. \\
\hline
\end{tabular}

Source: Authors' calculations based on ICRISAT (2017).

Note: Asterisks indicate the statistical significance: ${ }^{\star \star \star} 1 \%,{ }^{\star \star} 5 \%,{ }^{\star} 10 \%$. CRE $=$ correlated random effects; n.a. $=$ not applicable; SURE $=$ seemingly unrelated regression.

15 percent level). This result may be partly because of significant adoption of Bt cotton varieties in India observed lately in areas including those covered by VDSA data. Bt cotton may be more suitable for production on large farms than on smaller ones because its resistance to major pests can reduce the labor cost for pest control, particularly on large farms (Deininger and Byerlee 2012). Although the exact mechanisms need to be investigated in future studies, the results suggest potential interactions between tractors and certain improved varieties.

The adoption of combine harvesters seems to have mixed effects. Although yield effects on wheat are insignificant, those for rice in kharif season are significant, with the adoption of combine harvesters leading to about 
TABLE 3.14 Yield effects of tractor and combine harvester use on key crops

\begin{tabular}{lcccc}
\hline Dependent variable & \multicolumn{3}{c}{ Growth rate of yield $(1=100 \%$ increase) } \\
\hline Crop and season & $\begin{array}{c}\text { Rice } \\
\text { (kharif } \\
\text { season) }\end{array}$ & $\begin{array}{c}\text { Cotton } \\
\text { (kharif } \\
\text { season) }\end{array}$ & $\begin{array}{c}\text { Wheat } \\
\text { (rabi } \\
\text { season) }\end{array}$ & $\begin{array}{c}\text { Sugarcane } \\
\text { (annual) }\end{array}$ \\
\hline Whether using tractor or not (yes $=1$, no $=0)$ & .041 & .093 & -.080 & .045 \\
Whether using combine harvester or not (yes $=1$, no $=0)$ & $.235^{\star}$ & -.122 & -.191 & n.v. \\
Price of crop (natural log) & $.006^{\star *}$ & -.042 & .032 & .020 \\
Other household characteristics & Included & Included & Included & Included \\
Year dummies & Included & Included & Included & Included \\
Village dummies & Included & Included & Included & Included \\
Year * village dummies & Included & Included & Included & Included \\
Household fixed effects & Included & Included & Included & Included \\
Intercept & Included & Included & Included & Included \\
Number of observations & 443 & 601 & 422 & 479 \\
\hline
\end{tabular}

Source: Authors' calculations based on ICRISAT (2017).

Note: Asterisks indicate the statistical significance: ${ }^{\star \star \star} 1 \%,{ }^{\star \star} 5 \%,{ }^{*} 10 \%$. n.v. $=$ variables are dropped because there is no variation among the samples.

a 23.5 percent increase in yield, given the prevailing yield levels in the sample. This finding is consistent with the hypothesis that adopting combine harvesters can raise rice yield through reduced harvest loss associated with improved harvesting and threshing precision enabled by machines, among other things. The insubstantial effects for wheat indicate that the yield effects of combine harvester use could vary by crop.

\section{Effects on Seasonal Wage Variability}

To analyze seasonal wage variability, we use monthly microlevel VDSA data on seasonal wage rates in a particular Andhra Pradesh village, Aurapally. We analyze the seasonal and monthly variations in agricultural wages by taking the average rate in the village for each of four types of labor in each month of 2011 (Table 3.15).

Interestingly, the seasonal fluctuation (coefficient of variation) in the wage rate for female agricultural labor is six times higher than that of male labor. This result suggests that employment is more stable for men than women, who are hired largely for peak-season work; indeed, we see more fluctuation in demand for female labor than for male labor across the sampled 18 villages. Furthermore, the wage rate for women in India is almost 50 percent 
TABLE 3.15 Wage rates for agricultural labor (by sex), bullocks, and tractors in a typical dryland village in Andhra Pradesh, India, 2011

\begin{tabular}{lcccc}
\hline & \multicolumn{4}{c}{ Rupees per hour } \\
\cline { 2 - 5 } Month & $\begin{array}{c}\text { Bullock pair + } \\
\text { driver wage }\end{array}$ & $\begin{array}{c}\text { Female } \\
\text { labor wage }\end{array}$ & $\begin{array}{c}\text { Male } \\
\text { labor wage }\end{array}$ & $\begin{array}{c}\text { Tractor + } \\
\text { driver }\end{array}$ \\
\hline January & 600 & 118 & 200 & 600 \\
February & 610 & 88 & 190 & 465 \\
March & 610 & 93 & 200 & 430 \\
April & 570 & 84 & 200 & 550 \\
May & 650 & 93 & 210 & 510 \\
June & 775 & 138 & 200 & 585 \\
July & 580 & 141 & 194 & 568 \\
August & 610 & 127 & 210 & 570 \\
September & 640 & 135 & 205 & 520 \\
October & 610 & 124 & 200 & 600 \\
November & 610 & 126 & 200 & 520 \\
December & 570 & 104 & 200 & 550 \\
Average & 623 & 118 & 201 & 540 \\
Standard deviation & 55 & 21 & 6 & 53 \\
Coefficient of variation & 9 & 18 & 3 & 10 \\
\hline
\end{tabular}

Source: Authors' calculations based on ICRISAT (2017).

lower than that for men, except in the peak season of farm operation, June to November. The rate for a bullock pair and male operator for a day in 2011 was substantially higher than the rate for either a male or female worker, and the same as hiring a tractor and driver for a mere hour. A typical tractor of $40 \mathrm{hp}$ can plow almost 50 percent more area in an hour than a pair of animals can plow in a day. These findings illustrate the field-level economics behind the astonishing increase in tractor rentals among Indian farmers.

\section{Conclusions and Implications}

Historical review of the evolution of mechanization growth in India reveals important lessons about the drivers and impacts of mechanization. The spread of tractors despite the continuous decline in average farm size indicates that mechanization can grow even in a smallholder-dominated society through extensive custom hiring services, at least in the medium term, before the 
comparative advantage starts shifting toward larger farms as mechanization deepens. The speed of mechanization growth can vary considerably across regions, depending on agroecological conditions and farming and cropping systems. Although $4 \mathrm{WTs}$ are more common than power tillers, due possibly to the prevalence of rice-nonrice rotation and other soil-related constraints, a popular horsepower for $4 \mathrm{WTs}$ has been $30-50 \mathrm{hp}$.

Substantial infrastructure endowments (in terms of roads, for example), which were already high in the 1960s, as well as investments into rural electrification, were likely to have been important for the growth in domestic manufacturing of tractors. The promotion of importing tractors in the early days was likely to have helped farmers and technicians in India accumulate knowledge about tractors and parts. This knowledge, again, may have contributed to the growth of the domestic tractor manufacturing sector even as import restrictions in the 1970s were negatively affecting the continuous transfer of foreign tractor technologies. Over time, diverse models of providing custom hiring services for tractors and combine harvesters have begun to serve areas where such services are profitable, with relatively little direct support from the government. The government's direct support has instead concentrated on recent efforts to achieve inclusive growth by providing services to those left behind. With some subsidies, service providers for zero-till technologies and laser land leveling have also emerged. The private sector has also stepped up to provide facilitating services that connect service providers and farmers.

Empirical analyses of the impact of tractor ownership and tractor/combine harvester use confirm many of our hypotheses. Despite the typically small landholding in India, tractor ownership is led by the motive to expand farm size. Tractors are more bullock saving than labor saving, whereas combine harvesters are more strongly labor saving. This finding is consistent with the hypothesis that power requirements in Indian farming are much greater than can be met by human labor only, so that the returns on substituting tractors for human labor are substantial. These returns are an important precondition for custom hiring service providers to earn enough profit to provide services. Combine harvesters are more yield enhancing than tractors because the former are likely to directly reduce harvesting losses. Tractor adoption for land preparation, however, induces greater chemical fertilizer use, which may then lead to yield increases.

As for policy recommendations, Indian experiences offer a number of lessons to African countries. First, although India eventually developed domestic manufacturing industries for tractors and other major agricultural machinery, 
at an early stage the country followed less distorting tractor importation policies. Through such an approach, the country imported a diverse set of foreign tractors. The availability of such great diversity in designs, brands, and functions of machines stimulated learning by local engineers and fabricators, as well as local adaptations, and eventually helped the emergence of strong and vibrant manufacturing industries. Although taxes, tariffs, or both had been placed to raise government revenues, they were introduced only after overall demand and imports had grown sufficiently and the local manufacturing capacity had been raised sufficiently.

Second, though subsidies have long been provided for agricultural machinery, India has kept subsidy levels relatively low (25-33 percent) and instead has expanded the types of machines (including brands and designs) for which subsidies are applicable. Consequently, its subsidies have been less selective and distorting, and have contributed more to increasing the range of machines available in the market.

Third, significant support for finance, such as directing banks to reserve 11 percent of total credit for tractor purchases (in the 1980s) coincided with a significantly high share of tractors purchased with bank credit over time. The direction of causality remains unclear and the cost-effectiveness of this approach needs further investigation. The prevalence of relatively small 4WTs (with an average horsepower of 30) in India might have brought in more buyers who were wealthy enough to buy those tractors with some credit but not wealthy enough to buy larger, more expensive tractors-unlike in African countries, where only larger tractors are available, which can be bought only by wealthy individuals, who need no credit at all.

Last, the government has provided significant public goods. It has facilitated private-sector $\mathrm{R} \& \mathrm{D}$ in machines by developing designs for new equipment, educating engineers, and offering extension programs. Furthermore, significant public investments have been provided over time in infrastructure (road, irrigation) and complementary technologies (improved varieties and so on).

Though the economic, institutional, and political conditions in India differ from those of many African countries, the Indian experiences have been closer to the principles of a significant government focus on public goods provision and facilitation, with fewer distortions of the markets. These are likely to be important principles that African countries must follow in reforming their mechanization support policies. 


\section{References}

Arellano, M., and S. Bond. 1991. "Some Tests of Specification for Panel Data: Monte Carlo Evidence and an Application to Employment Equations." Review of Economic Studies 58: 277-297.

Arellano, M., and O. Bover. 1995. "Another Look at the Instrumental Variables Estimation of Error-Components Model." Journal of Econometrics 68: 29-52.

Aurora, G. S., and A. Morehouse. 1972. "Dilemma of Technological Choice: The Case of the Small Tractor." Economic and Political Weekly 7 (31/33): 1633-1644.

Babu, S. C., and A. Hallam. 1989. "Evaluating Agricultural Energy Policies under Uncertainty: The Case of Electricity in South India." Agricultural Economics 3 (3): 187-198.

Bationo, A., B. Waswa, J. M. Okeyo, F. Maina, and J. M. Kihara, eds. 2011. Innovations as Key to the Green Revolution in Africa. Vol. 1, Exploring the Scientific Facts. New York: Springer Science + Business Media.

Bell, M. A., D. Dawe, and M. B. Douthwaite. 1998. Increasing the Impact of Engineering in Agricultural and Rural Development: Deliberations of a Think Tank, 26-28 February 1998, IRRI, Los Baños, Philippines. Discussion Paper 30. Manila: International Rice Research Institute.

Bhattarai, M., P. K. Joshi, R. S. Shekhawat, and H. Takeshima. 2017. The Evolution of Tractorization in India's Low-Wage Economy: Key Patterns and Implications. IFPRI Discussion Paper 01675. Washington, DC: International Food Policy Research Institute.

Bhattarai, M., G. Singh, H. Takeshima, and S. Shekhawat. 2018. Farm Machinery Uses and Agricultural Industries in India: Status, Evolution, Implications, and Lessons Learned. IFPRI Discussion Paper 01715. Washington, DC: IFPRI.

Bhattarai, M., B. L. Varalakshmi, P. R. Pandey, A. B. Dhumale, and C. Bantilan. 2015. "Whether Combine Harvester Is Speeding Up Rural Transformation in India?" Poster presented at Village Dynamics in South Asia workshop at International Crops Research Institute for the Semi-Arid Tropics, Hyderabad, India, March. http://vdsa.icrisat.ac.in/Include/posters /Poster28.pdf.

Binswanger, H. 1978. The Economics of Tractors in South Asia: An Analytical Review. New York: Agricultural Development Council; Hyderabad: International Crops Research Institute for the Semi-Arid Tropics.

_. 1986. "Agricultural Mechanization: A Comparative Historical Perspective." World Bank Research Observer 1 (1): 27-56.

Binswanger, H., and G. Donovan. 1987. Agricultural Mechanization: Issues and Options. Washington, DC: World Bank. 
Blundell, R., and S. Bond. 1998. "Initial Conditions and Moment Restrictions in Dynamic Panel Data Models." Journal of Econometrics 87: 115-143.

Carranza, E. 2014. "Soil Endowments, Female Labor Force Participation, and the Demographic Deficit of Women in India." American Economic Journal: Applied Economics 6 (4): 197-225.

Chamberlain, G. 1984. "Panel Data." In Handbook of Econometrics. Vol. 2, ed. Z. Grilliches and M. D. Intriligator, 1247-1318. Amsterdam: North-Holland.

Chauhan, B. S., G. Mahajan, V. Sardana, J. Timsina, and M. L. Jat. 2012. "Productivity and Sustainability of the Rice-Wheat Cropping System in the Indo-Gangetic Plains of the Indian Subcontinent: Problems, Opportunities, and Strategies." Advances in Agronomy 117 (1): $315-369$.

CSAM (Centre for Sustainable Agricultural Mechanization). 2014. "Country Pages: India.” Accessed February 25, 2018. http://un-csam.org/PPT/in-index.htm.

Deininger, K., and D. Byerlee. 2012. "The Rise of Large Farms in Land-Abundant Countries: Do They Have a Future?” World Development 40 (4): 701-714.

Desai, A. 1981. Interfuel Substitution in the Indian Economy. Energy in Developing Countries Discussion Paper D-73B. Washington, DC: Resources for the Future.

Fan, S., P. Hazell, and S. Thorat. 2000. "Government Spending, Agricultural Growth and Poverty in Rural India." American Journal of Agricultural Economics 82 (4): 1038-1051.

FAO (Food and Agriculture Organization of the United Nations). 2018. AQUASTAT database. Accessed March 2. www.fao.org/nr/water/aquastat/main/index.stm.

Farrington, J. 1986. "Mechanization Policy and the Impact of Tractors in South Asia: A Review." In Small Farm Equipment for Developing Countries: Proceedings of the International Conference on Small Farm Equipment for Developing Countries: Past Experiences and Future Priorities, 2-6 September 1986, 85-124. Los Baños, Philippines: International Rice Research Institute.

FICCI (Federation of Indian Chambers of Commerce and Industry). 2015. Transforming Agriculture through Mechanization: A Knowledge Paper on Indian Farm Equipment Sector. New Delhi: Grant Thornton India. http://ficci.in/spdocument/20682/agrimach.pdf.

Goel, H., and V. Kumar. 2013. Automobiles: Sixth Gear. Mumbai: Kotak Securities Ltd.

Henderson, H., L. Corral, E. Simning, and P. Winters. 2015. "Land Accumulation Dynamics in Developing Country Agriculture.” Journal of Development Studies 51 (6): 743-761.

ICRISAT (International Crops Research Institute for the Semi-Arid Tropics). 2017. Village Dynamics in South Asia Dataset 2001-2014. Hyderabad, India. http://vdsa.icrisat.ac.in /vdsa-database.aspx. 
India, MOAFW (Ministry of Agriculture and Farmers' Welfare). 2015. Agricultural Mechanization Sub-Mission (SMAM): A Brief. New Delhi.

India, MOEIT (Ministry of Electronics and Information Technology). 2018. "Agro Climatic Zones in India." Accessed March 2. http://vikaspedia.in/agriculture/crop-production /weather-information/agro-climatic-zones-in-india.

IRRI (International Rice Research Institute). 2010. Rice in the Global Economy: Strategic Research and Policy Issues for Food Security. Los Baños, Philippines.

Ito, S. 1986. "Modifying Imported Technology by Local Engineers: Hypotheses and Case Study of India." Developing Economies 24 (4): 334-348.

Jayasuriya, S. K., A. Te, and R. H. Herdt. 1986. "Mechanization and Cropping Intensification: Economics of Machinery Use in Low-Wage Economies." Journal of Development Studies 22 (2): 327-335.

Keil, A., A. D’Souza, and A. McDonald. 2016. “Growing the Service Economy for Sustainable Wheat Intensification in the Eastern Indo-Gangetic Plains: Lessons from Custom Hiring Services for Zero-Tillage." Food Security 8 (5): 1011-1028.

Larsen, B. 1994. World Fossil Fuel Subsidies and Global Carbon Emissions in a Model with Interfuel Substitution. Policy Research Working Paper 1256. Washington, DC: World Bank.

Mohan, C. 1986. "Establishment of the Tractor Industry in India." In Small Farm Equipment for Developing Countries: Proceedings of the International Conference on Small Farm Equipment for Developing Countries: Past Experiences and Future Priorities, 2-6 September 1986, 161172. Los Baños, Philippines: International Rice Research Institute.

Morehouse, W. 1980. “Technology and Enterprise Performance in the Indian Tractor Industry: Does Self-Reliance Measure Up?” Economic and Political Weekly 15 (51): 2139-2152.

Moulik, T. K. 1988. “Energy and Development Options: The Case of India." Journal of Energy and Development 13 (2): 239-273.

Mukherjee, S. K. 1978. Energy Consumption in India: Recent Trends and the Problem of Demand Forecasting. Working Paper 198. Ahmedabad: Indian Institute of Management.

Patel, N. T., and M. Gandhi. 1996. Profile and Impacts of Tractorization. Working Paper 1305. Ahmedabad: Indian Institute of Management.

Pingali, P. 2007. “Agricultural Mechanization: Adoption Patterns and Economic Impact." In Handbook of Agricultural Economics. Vol. 3, Agricultural Development: Farmers, Farm Production and Farm Markets, edited by R. Evenson and P. Pingali, 2779-2805. Amsterdam: Elsevier.

Pray, C. E., and L. Nagarajan. 2014. "The Transformation of the Indian Agricultural Input Industry: Has It Increased Agricultural R\&D?” Agricultural Economics 45 (S1): 145-156. 
Rao, Y. M., K. Ravi Chand, V. R. Kiresur, and M. C. S. Bantilan. 2011a. Documentation of Second-Generation Village-Level Studies (VLS) in India (Part I: 2001-02 to 2004-05). Patancheru, India: International Crops Research Institute for the Semi-Arid Tropics.

- 2011b. Documentation of Second-Generation Village-Level Studies (VLS) in India, 2005-06 to 2008-09. Patancheru, India: International Crops Research Institute for the Semi-Arid Tropics.

Roodman, D. 2009. "How to Do xtabond2: An Introduction to Difference and System GMM in Stata." Stata Journal 9 (1): 86-138.

Sarkar, A. 2013. "Tractor Production and Sales in India, 1989-2009." Review of Agrarian Studies 3 (1): $55-72$.

Sarkar, H., and G. K. Kadekodi. 1988. Energy Pricing in India: Perspective, Issues, and Options. Geneva, Switzerland: International Labour Organization.

Shah, C. J., and S. Kanodia. 2015. Farm Mechanisation: Way Forward for Indian Agriculture. Mumbai: ICICI Securities Ltd. http://content.icicidirect.com/mailimages/IDirect_ FarmMechanisation_ThematicReport.pdf. Accessed April 17.

Shonkwiler, J. S., and S. T. Yen. 1999. “Two-Step Estimation of a Censored System of Equations.” American Journal of Agricultural Economics 81 (4): 972-982.

Singh, C. P., S. R. Verma, and S. K. Tandon. 1984. "Status of Agricultural Mechanization in India." In Development of the Agricultural Machinery Industry in Developing Countries: Proceedings of the 2nd International Conference, Amsterdam, 23-26 January 1984, edited by A. Moens and A. H. J. Siepman, 99-115. Wageningen, Netherlands: Center for Agricultural Publishing and Documentation.

Singh, G. 1998. "Production and Use of Tractors in India." In Increasing the Impact of Engineering in Agricultural and Rural Development, edited by M. A. Bell, D. Dawe, and M. B. Douthwaite, 49-60. Discussion Paper 30. Los Baños, Philippines: International Rice Research Institute.

- 2015. "Agricultural Mechanization Development in India." Indian Journal of Agricultural Economics 70 (1): 64-82.

Singh, K. N. 1978. "Status of Agricultural Mechanization in Southeast and East India." In Proceedings of the International Agricultural Machinery Workshop, 43-58. Los Baños, Philippines: International Rice Research Institute.

Singh, R. S., S. Singh, and S. P. Singh. 2015. "Farm Power and Machinery Availability on Indian Farms." Agricultural Engineering Today 39 (1): 45-56.

Singh, S., H. S. Kingra, and Sangeet. 2013. "Custom Hiring Services of Farm Machinery in Punjab: Impact and Policies." Indian Research Journal of Extension Education 13 (2): 45-50. 
Srinivasan, T. N. 1981. Food Security: Indian Perspective. Discussion Paper 373. New Haven, CT, US: Economic Growth Center, Yale University.

Suri, M. M. 1978. “Agricultural Mechanization in India." In Proceedings of the International Agricultural Machinery Workshop, 33-42. Los Baños, Philippines: International Rice Research Institute.

Takeshima, H. 2017. "Custom-Hired Tractor Services and Returns to Scale in Smallholder Agriculture: A Production Function Approach." Agricultural Economics 48 (3): 363-372. Takeshima, H., R. Adhikari, S. Shivakoti, B. D. Kaphle, and A. Kumar. 2017. "Heterogeneous Returns to Chemical Fertilizer at the Intensive Margins: Insights from Nepal.” Food Policy 69: 97-109.

\section{Appendix 3A: Empirical Methods}

\section{Effects on Farm Size and Farm Size Dynamics}

The role of tractor ownership in farm size dynamics is estimated by modifying the specifications provided by Henderson and colleagues (2015) for the dynamic growth patterns of farms in Paraguay. The regression equations and the empirical results of the regression models are provided below.

Specifically, we estimate the equation

$$
\begin{aligned}
& \Delta \ln y_{i t}=\alpha+\beta_{1} \ln y_{i, t-1}+\beta_{2}\left(\operatorname{lny}_{i, t-1}\right)^{2}+\beta_{3} \ln (\text { land owned })_{i, t-1} \\
& +\beta_{4} \text { tractor }_{i, t-1}+\beta_{5} z_{i t}+\varepsilon_{i t},
\end{aligned}
$$

where

- $y_{i t}=$ the operational land size of farm household $i$ in year $t$,

- $\Delta=$ the difference in variables between years $t$ and $t-1$,

- tractor $_{i, t-1}=$ the number of tractors owned in $t-1$, and

- $z_{i t}=$ the other socioeconomic characteristics of the households.

Other variables include labor endowments (working-age household members), dependency (the number of children and elders), education of the household head, household members' ages, and so on. The other characteristics added are similar to those used by Henderson and others (2015). As in Henderson and others (2015), equation (1) is estimated using the dynamic 
panel methods developed by Arellano and Bond (1991), Arellano and Bover (1995), and Blundell and Bond (1998), which also address the peculiar endogeneity issues between variables $y_{i, t-1}$ and tractor $_{i, t-1}$.

Specifically, we estimate equation (1) using system generalized method of moments (GMM) methods, which are often considered more efficient than difference GMM methods (Roodman 2009). The models are estimated using the xtabond 2 command in Stata. We use lagged values of the differences between $y_{i, t-1}$ and $\left(y_{i, t-1}\right)^{2}$, and of tractor $_{i, t-1}$, up to a certain period, as the excluded instrumental variables (IVs) to instrument the potentially endogenous variables, together with all the exogenous variables included in the model. The bottom row of Table 3.9 displays the specific lag periods used as IVs. The validity of the instruments is tested by a Hansen test of overidentification, and autocorrelation is also tested, with results of both tests shown near the bottom of Table 3.9. The $p$-values indicate that the model satisfies the conditions of these tests.

\section{Effects on Land Productivity and Adoption of Other Modern Technologies}

The effects of mechanization (tractor and combine harvester use) on farmers' various behaviors are assessed in the following panel data equation framework:

$$
y_{i t}=\alpha+c_{i}+M_{i t} \beta+A_{i t} \gamma+z_{i t} \delta+\varepsilon_{i t},
$$

where $y_{i t}$ is the outcome of interest (labor use, bullock use, use of modern inputs such as chemical fertilizer, or yield), $M_{i t}$ is the use of machines (tractors or combine harvesters), $A_{i t}$ is the area cultivated, and $z_{i t}$ is the vector of other exogenous variables. Variable $z_{i t}$ includes time-variant household characteristics, such as household size (breaking out working-age members and dependents), completed education of the household head (in years), farming experience of the household head (years), gender and age of the household head, prices of various inputs or services (chemical fertilizer price, male labor wages, land purchase or rental price, tractor rental price), whether using irrigation or not (yes $=1$ ), value of agricultural capital, and year-village interaction terms to control for other village-specific shocks in each year. ${ }^{16}$

16 Year-village interaction dummies account for various shocks that may affect many households within the village. They may include weather-related shocks, local-level government interventions, or technological shocks such as the diffusion of new varieties in the area, all of which can affect outcomes separately from the effects of tractor or combine harvester use. 
Variables $M_{i t}$ and $A_{i t}$ are potentially endogenous, so we also estimate this relationship using IV estimation methods. ${ }^{17}$ We find, however, that the fixed-effects model generally eliminates the endogeneity bias. Equation (2) is also estimated using a censored regression model, as several outcome variables contain values of 0 . Importantly, the outcomes of interest-labor use, bullock use, chemical fertilizer, and yield — are correlated with each other, including correlation among idiosyncratic errors, $\varepsilon_{i t}$, across equation (2) for each outcome. We therefore estimate (2) as a system of equations, rather than estimating it separately for each outcome. Specifically, equation (2) is estimated in two ways. First, we estimate a seemingly unrelated regression using within-transformed variables, which is equivalent to a system of fixed-effects panel, ordinary least squares regressions. Second, we estimate a system of the censored regression model (Shonkwiler and Yen 1999) combined with Chamberlain (1984)-type correlated random effects approximated by average values of exogenous variables over time, which is essentially a system of panel tobit regressions.

\section{EFFECTS OF TRACTOR AND COMBINE HARVESTER USE ON YIELDS OF KEY CROPS}

We estimate

$$
y_{i j t}=\alpha+c_{i j}+M_{i j t} \beta+P_{i j t}+z_{i t} \delta+\varepsilon_{i t}
$$

in which $y_{i j t}$ is the natural $\log$ of the yield of the crop grown by household $i$ in year $t$. Here, notation $j$ is added to indicate that the model controls for plot, season, and variety. The set of variables is similar to those for equation (2), except that here we drop area, $A_{i t}$, which is part of the dependent variable, and add $P_{i j t}$, the price of the crop, which is specific to variety, plot, and season.

17 Generally, the IVs used include the rental fees for the respective machines and the land value per acre. Their natural log transformations are also included to account for potentially nonlinear relations between these price variables and the values for the use of machines or the area cultivated. 
